OPEN ACCESS

Edited by:

Gaetano Santulli,

Columbia University, United States

Reviewed by:

Sylvaine You,

Institut National de la Santé et de la

Recherche Médicale, France

Urs Christen,

Goethe University Frankfurt, Germany

Evie Melanitou,

Institut Pasteur, France

*Correspondence:

Brian T. Fife

bfife@umn.edu

Specialty section: This article was submitted to Diabetes,

a section of the journal

Frontiers in Endocrinology

Received: 03 October 2017 Accepted: 21 November 2017 Published: 05 December 2017

Citation:

Burrack AL, Martinov T and Fife BT (2017) T Cell-Mediated Beta Cell

Destruction: Autoimmunity and Alloimmunity in the Context of Type 1 Diabetes.

Front. Endocrinol. 8:343. doi: 10.3389/fendo.2017.00343

\section{T Cell-Mediated Beta Cell Destruction: Autoimmunity and Alloimmunity in the Context of Type 1 Diabetes}

\author{
Adam L. Burrack, Tijana Martinov and Brian T. Fife* \\ Department of Medicine, Center for Immunology, University of Minnesota Medical School, Minneapolis, MN, United States
}

Type 1 diabetes (T1D) results from destruction of pancreatic beta cells by $T$ cells of the immune system. Despite improvements in insulin analogs and continuous blood glucose level monitoring, there is no cure for T1D, and some individuals develop life-threatening complications. Pancreas and islet transplantation have been attractive therapeutic approaches; however, transplants containing insulin-producing cells are vulnerable to both recurrent autoimmunity and conventional allograft rejection. Current immune suppression treatments subdue the immune system, but not without complications. Ideally a successful approach would target only the destructive immune cells and leave the remaining immune system intact to fight foreign pathogens. This review discusses the autoimmune diabetes disease process, diabetic complications that warrant a transplant, and alloimmunity. First, we describe the current understanding of autoimmune destruction of beta cells including the roles of CD4 and CD8 T cells and several possibilities for antigen-specific tolerance induction. Second, we outline diabetic complications necessitating beta cell replacement. Third, we discuss transplant recognition, potential sources for beta cell replacement, and tolerance-promoting therapies under development. We hypothesize that a better understanding of autoreactive $T$ cell targets during disease pathogenesis and alloimmunity following transplant destruction could enhance attempts to re-establish tolerance to beta cells.

\footnotetext{
Keywords: type 1 diabetes, immunology, autoimmune diseases, transplantation immunology, tolerance induction, T cells, alloimmunity
}

\section{INTRODUCTION}

Pancreatic beta cells are destroyed by $\mathrm{T}$ cells of the immune system, precipitating type 1 diabetes (T1D). Unfortunately, preventing beta cell destruction in at-risk individuals has proven challenging. Despite a working knowledge of genetic risk factors associated with T1D (1), determining specific beta cell targets and preventing beta cell destruction by autoreactive $\mathrm{T}$ cells remains elusive. To develop a successful approach to protect beta cells, we must understand how and why T cells are directed to specifically destroy insulin-producing cells in the pancreas while sparing adjacent hormone-producing cells including alpha, delta, and epsilon cells. There may be at least two paths to protect beta cells from $\mathrm{T}$ cell-mediated death. The first approach is to control or regulate effector 
T cell responses, and the second is to enhance beta cell survival or resistance to $\mathrm{T}$ cell-mediated death.

The first section of this review outlines our current understanding of the pathogenesis of autoimmune diabetes. We describe the process by which insulin-producing beta cells are destroyed and contrast the roles of $\mathrm{CD} 4^{+}$and $\mathrm{CD} 8 \mathrm{~T}$ cells during autoimmune pathogenesis. We compare T1D pathogenesis in the non-obese diabetic (NOD) mouse to our current understanding of human disease. We also discuss an exciting recent development in the field of autoreactive $\mathrm{T}$ cell biology: recognition of neoantigens generated through hybrid peptide fusion or response to neoantigens formed through defective protein translation. Finally, we describe immune tolerance in several forms, including thymic central tolerance, $\mathrm{T}$ cell ignorance in the periphery, anergy, and regulatory $\mathrm{T}$ cell induction.

The second section of this review briefly describes the necessity for pancreas or islet transplantation to treat severe diabetic complications. With improving glycemic control through insulin injections and continuous glucose monitoring, many T1D individuals live with minimal complications $(2,3)$. However, some T1D individuals develop life-threatening complications including hypoglycemia unawareness and end-stage renal disease. Unawareness of severe hypoglycemia is a primary indicator for pancreas or islet transplantation and is often combined with kidney transplantation to treat renal failure.

The third section of this review focuses on islet replacement strategies and briefly outlines beta cell regeneration. The two primary avenues for beta cell replacement are transplantation of cadaveric islets or induced pluripotent stem cell (iPS)-derived beta cells. While there has been considerable progress in both strategies, a cure for established T1D must also involve targeted immunotherapy. This approach must inhibit memory autoreactive $\mathrm{T}$ cells and naive allograft-reactive immune responses. In the third section of this review, we describe allorecognition, or how T cells "see" transplants, focusing on pancreatic islet transplantation. We describe two categories of allorecognition by $\mathrm{T}$ cells in transplant recipients: direct recognition of donor major histocompatibility complex (MHC) molecules and indirect recognition of transplant-derived peptides through recipient $\mathrm{MHC}$ molecules. We also discuss the challenges of transplant tolerance in the NOD mouse and human T1D islet allograft recipients. Recent evidence suggests that the presence of autoimmunity acts as an "adjuvant," accelerating and strengthening the conventional alloimmune response.

\section{AUTOIMMUNE DIABETES PATHOGENESIS}

Type 1 diabetes is a T cell-mediated autoimmune disease, whereas T2D is the result of peripheral cell resistance to endogenous insulin. The best evidence supporting immune system involvement in T1D are studies reporting lymphocytic infiltrate in the islets of T1D cadaveric donors $(4,5)$, islet-specific autoantibody production in individuals with T1D (6-8), and identical twin studies in which the twin with T1D rejected islet transplants from their non-diabetic twin (9). Analyses of pancreas sections harvested from individuals with T1D have shown fulminant immune infiltration within individual islets, corroborating a key role for
CD4 and CD8 T cells in beta cell destruction (10-12). This is in sharp contrast to pancreas sections from individuals with T2D, who, despite having high levels of systemic inflammatory markers, do not have similar T cell infiltration within pancreatic islets (10-12). Virtually all individuals who develop T1D before the age of 5 years produce insulin-specific autoantibodies (IAAs), suggesting an important role for peptides derived from the insulin molecule in disease pathogenesis $(13,14)$. Islet autoantibodies are a differential diagnosis marker for T1D versus T2D and arise from autoreactive B cell and autoreactive CD4 T cell interactions. Human leukocyte antigens (HLAs) class II alleles DR4, DQ8, and DQ2 confer the highest genetic risk for T1D in human patients (15). This strong HLA II allele association with T1D suggests that HLA II-restricted CD4 T cells play a key role in disease pathogenesis. CD4 T cells can provide "help" to B cells and stimulate antibody production as noted above, as well as promote responses by effector CD8 T cells, and stimulate islet-resident macrophages $(16,17)$. With this in mind, autoreactive CD4 T cells represent an active area of research and clinical interest for therapies. Developing antigen-specific tolerance-promoting methods to inhibit autoreactive CD4 T cells is the focus of the first section of this review.

\section{The NOD Mouse Model of T1D}

The NOD mouse was first characterized at the Shionogi Research Laboratories in Aburahi, Japan, by Makino et al. (18). The NOD mouse was developed as a sub-strain of the JcI:ICR mouse strain, which was used to study cataract development (18). The NOD strain exhibited very high fasting blood sugar levels but not cataracts and has been an invaluable tool for T1D research. Depending on the colony, 50-90\% of female NOD mice develop spontaneous autoimmune diabetes between 10 and 30 weeks of age (19). Generally, diabetes onset in male NOD mice is much less frequent ( $20 \%$ in the same age range); therefore the majority of studies of autoimmune diabetes utilizing this strain of mice use female diabetic mice (20). This review will focus on spontaneous autoimmune diabetes pathogenesis in NOD mice, although other models of beta cell destruction mediated by T cell receptor (TCR) transgenic $\mathrm{T}$ cells targeting ectopically expressed antigen such as in rat insulin promoter (RIP) driving lymphocytic choriomeningitis virus (21) RIP-membrane-bound form of ovalbumin (22) or insulin hemagglutinin (23) have contributed extensively to our understanding of T1D and are discussed elsewhere (24). Studies in the NOD mouse demonstrate a strong dependence on MHC class II allele I- $\mathrm{A}^{\mathrm{g} 7}$ and the requirement of CD4 T cells (25), CD8 T cells (26), and B cells $(27,28)$ for autoimmune diabetes. Interestingly, diabetes-associated MHC II, I-A ${ }^{97}$ does not precipitate diabetes when expressed in non-autoimmune-prone B6 mice (29), but NOD mice engineered to express MHC class II alleles other than $\mathrm{I}-\mathrm{A}^{\mathrm{g} 7}$ are protected from disease development (30). Collectively, these findings suggest that $\mathrm{I}-\mathrm{A}^{\mathrm{g} 7}$ is necessary, but not sufficient, for autoimmune diabetes. The roles of CD4 T cells, CD8 T cells, and $\mathrm{B}$ cells in diabetes pathogenesis are discussed below.

CD4 T cells are thought to provide help to effector CD8 T cells, stimulate antibody production by $\mathrm{B}$ cells, and activate isletresident M1 macrophages (Figure 1). CD4 T cells are required for diabetes development in NOD mice (31), and either depletion 

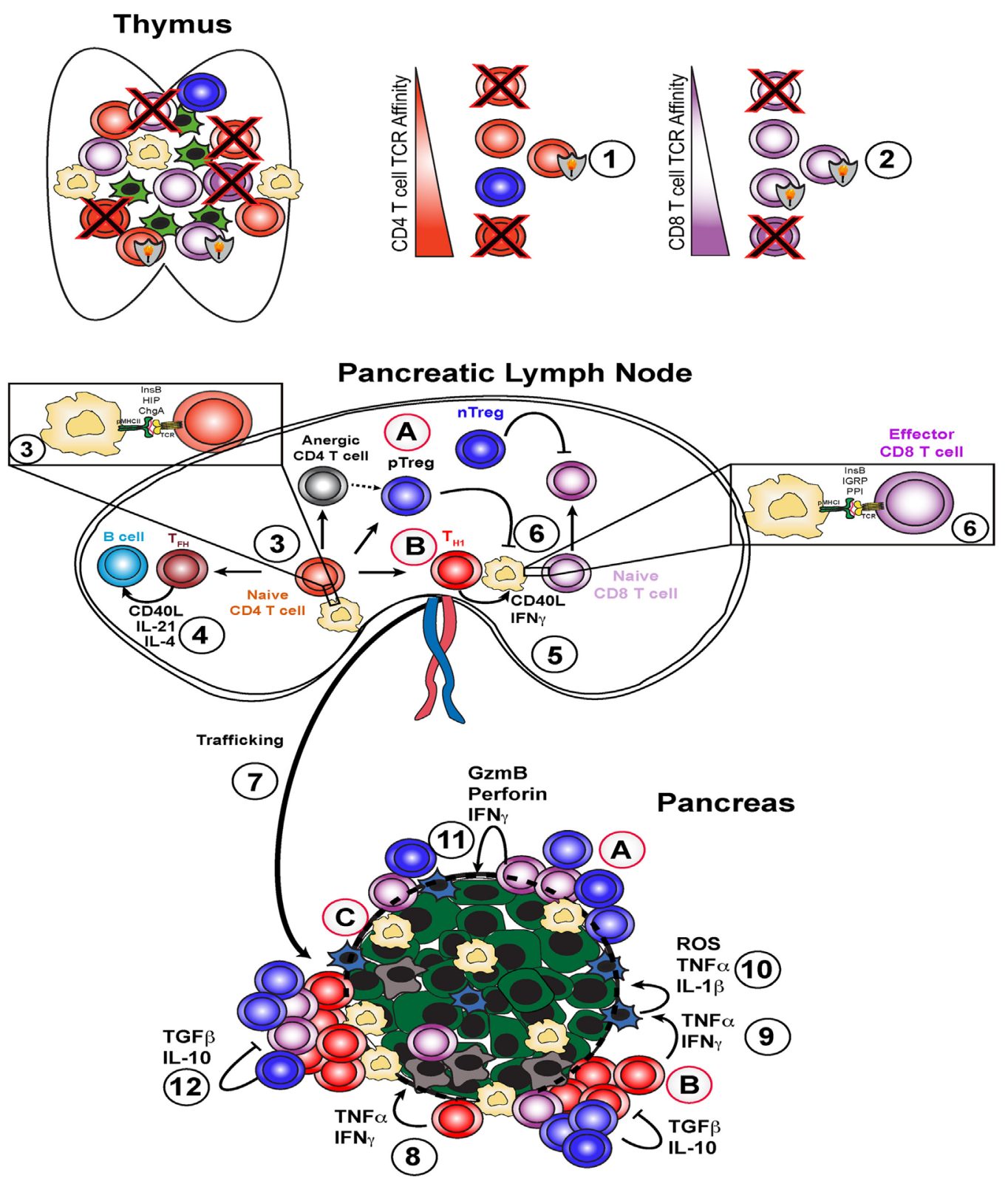

Legend

(1)

FIGURE 1 | Type 1 diabetes pathogenesis and potential therapeutic avenues. Type 1 diabetes arises due to failure of several key checkpoints. Defective central tolerance (1 and 2) allows islet-reactive CD4 and CD8 T cells to escape the thymus as naive cells and reach the pancreatic lymph node. In the pancreatic lymph node, autoreactive CD4 T cells interact with dendritic cells presenting islet antigen (3) and can become $T$ helper 1 ( $T_{H 1}$ ), $T_{F H}$, pTreg, or anergic cells. $T_{F H}$ cells help $\mathrm{B}$ cells produce high affinity islet-specific antibodies (4). $T_{H 1}$ cells activate dendritic cells and enhance antigen presentation to islet-specific $\mathrm{CD} 8 \mathrm{~T}$ cells (5) to induce effector CD8 T cell skewing (6). $\mathrm{T}_{\mathrm{H} 1}$ cells traffic to the pancreas (7), secrete pro-inflammatory cytokines interferon gamma (IFN $\gamma$ ) and TNF $\alpha$, and induce beta cell death (8). $\mathrm{T}_{\mathrm{H} 1}$-derived IFN $\gamma$ and TNF $\alpha$ stimulate M1 macrophages in the islets to produce ROS, TNF $\alpha$, and IL-1 $\beta$ (9), which in turn amplify beta cell death cycle (10). Resulting inflammation leads to increased CD8 T cell infiltration and direct beta cell killing via perforin and granzyme B (11) and attempts by $n$ Tregs and pTregs to dampen this response via TGF $\beta$ and IL-10 (12). Potential therapeutic strategies include (A) infusion of ex vivo expanded (broadly reactive or pancreas-specific) Tregs, (B) re-educating $\mathrm{T}_{\mathrm{H} 1}$ cells through approaches like peptide-linked apoptotic splenocytes, and (C) promoting beta cell-intrinsic expression of defense molecules in situ or engineering transplanted beta cells to be more resistant to T cell-mediated attack. 
of CD4 T cells (32) or treatment with non-depleting anti-CD4 antibodies prevents diabetes (33). Early research in the NOD mouse model demonstrated that $\mathrm{T}$ helper 1 cells transferred to neonatal NOD recipient mice could precipitate diabetes (34). Recent studies in NOD mice and human T1D patients have characterized the diabetogenic CD4 T cells as pro-inflammatory, capable of secreting interferon gamma (IFN- $\gamma$ ) and/or interleukin 17 (35-39). Interestingly, HLA-matched healthy donors may also have CD4 T cells with islet antigen specificity, but in their case, the cell phenotype and functional output is regulatory, with a cytokine profile consisting mainly of IL-10 $(35,36)$. CD4 T cell targets are peptides restricted to HLA or MHC II and are discussed in further detail below. In human T1D, the available evidence from studies of individual islets from the Network for Pancreatic Organ Donors with Diabetes suggests that beta cell destruction is mediated in large part through direct CD8 T cell contact with beta cells and CD4 T cell-mediated polarization of M1 macrophages $(4,10,40)$. CD4 regulatory $\mathrm{T}$ cells will be addressed below.

Autoreactive CD8 T cells are activated through interaction with peptides presented by MHC class I and can mediate beta cell death in a contact-dependent manner through perforin and granzyme molecules (Figure 1) (41). MHC class I is required for $\mathrm{T} 1 \mathrm{D}$, with some reports suggesting that CD8 T cell/MHC class I interactions are required only early in disease development (42), whereas others have concluded that MHC class I is required late in diabetes pathogenesis (43). Insulin-specific CD8 T cells are key for diabetes onset in both mouse $(44,45)$ and humans $(46)$. Even though CD8 T cells are required for disease pathogenesis, due to space limitations, the bulk of this review will focus on the biology of CD4 T cells.

Beta cell death can also be mediated through cytokine production by both CD4 and CD8 T cells within pancreatic islets. Proinflammatory cytokines such as TNF- $\alpha$ and IFN- $\gamma$ are directly toxic to beta cells (Figure 1) $(47,48)$. These cytokines also activate macrophages to M1 phenotype and stimulate a positive feedback loop, further increasing cytokine production in situ and killing more beta cells (Figure 1) (49). In addition, data from mouse and human samples demonstrate that beta cells can express the IFN- $\boldsymbol{\gamma}$-inducible chemokine CXCL10, which promotes $\mathrm{T}$ cell infiltration and may accelerate beta cell destruction $(50,51)$. Data from adoptive CD4 T cell transfer model of diabetes in the NOD mouse model suggest that M1 macrophages are required for beta cell destruction in this setting (52). Indeed, it has been demonstrated in the NOD mouse that superoxide production by $\mathrm{T}$ cells or macrophages is critical to promote beta cell death and T1D (16) and that loss of superoxide production by macrophages delays diabetes pathogenesis (53). Moreover, transient depletion of islet-infiltrating dendritic cells and macrophages using clodronate-loaded liposomes abrogated $\mathrm{T}$ cell infiltration and significantly delayed subsequent diabetes development in liposome-treated mice (54). More recent work has demonstrated a critical role for dendritic cells expressing the Batf3 transcription factor in autoimmune pathogenesis of NOD mice (55). Taken together, these results suggest that antigen presentation to CD4 T cells by dendritic cells and macrophages within pancreatic islets plays a key role in promoting beta cell destruction.
Finally, our current understanding is that B cells act as antigen-presenting cells to both CD4 and CD8 T cells and also produce IAAs (Figure 1) (56). Early studies established that NOD mouse production of IAA peaks between 8 and 12 weeks of age and gradually decreases afterward presumably as beta cell mass decreases $(57,58)$. In addition, $>60 \%$ of mice which developed IAA at 3-5 weeks of age develop T1D by week 20 , while $>50 \%$ of IAA-positive mice at 8 weeks of age develop T1D by week 20 (57-59). Translating these results to human patients, as pioneered by Eisenbarth (58), autoantibody responses against multiple different $\mathrm{T}$ cell antigens are highly predictive of diabetes onset within 12-36 months in human subjects $(1,8,60)$. In addition, recent work from Finland has demonstrated that high proportions of children with IAA and/or multiple autoantibodies against beta cell targets at ages younger than 5 years develop T1D (61). As shown by sibling studies (DAISY, TEDDY), the presence of one known autoantibody response confers a moderate risk level, with risk of imminent development of diabetes increasing exponentially with the detection of each additional autoantibody response.

While analogous experiments have not been performed using human autoreactive $\mathrm{T}$ cells and human beta cells in an in vitro setting or humanized mouse system, studies in the NOD mouse have elucidated potential mechanisms of beta cell destruction in human T1D, in particular key roles for CD4 and CD8 T cells. However, there are important differences between NOD and human T1D. In particular, there is a gender bias in NOD mice, with higher incidence in female than male mice $(19,20)$. In contrast, human T1D does not show gender bias, unlike other autoimmune diseases. A full account of the physiology behind this discordance is outside the scope of this review, but may include (a) more synchronous $\mathrm{T}$ cell infiltration into pancreatic islets in NOD mice than in at-risk human subjects, (b) the potential for a greater dependence on CD8 T cells in diabetes pathogenesis in human disease (10), and (c) confounding effects of multiple concurrent $\mathrm{T}$ cell responses in human patients exposed to the "universe" of viral and bacterial pathogens as opposed to inbred specific pathogen-free NOD mouse colonies.

\section{Autoimmune Diabetes Antigens and Neoantigens}

Diabetes-relevant antigen targets have been defined through the presence of serum autoantibodies, ELISpot assays, proliferation assays, and mouse studies [reviewed in Ref. (62)]. In mice and humans, some of the $\mathrm{B}$ cell and $\mathrm{T}$ cell antigen targets of T1D are overlapping, but not identical (63). The majority of autoantigens identified in the NOD mouse are peptides from the insulin secretory granules. At the Barbara Davis Center in the late 1980s, Haskins et al. $(64,65)$ and Wegmann et al. (66) utilized the NOD mouse to generate a series of pancreatic islet secretory granule-specific autoreactive CD4 T cell lines (67). Chief among these, the BDC2.5 CD4 T cell line has been studied extensively (68). Two key transgenic mouse lines were generated including the BDC2.5 TCR transgenic mouse (69) and the isletspecific glucose-6-phosphatase catalytic subunit-related protein (IGRP)-specific CD8.3 transgenic mouse (70). The NOD mouse 
has proven to be a useful "work horse" model system for studying the pathogenesis and cellular immunology of spontaneous and adoptively transferred T1D. T cell-mediated destruction of beta cells represents an intricate coordination between innate and adaptive lymphocytes, with CD4 T cells occupying a key node in this network, as described above. CD4 T cell epitopes discovered to date include epitopes derived from the insulin B chain (45), chromogranin A (71), and islet amyloid polypeptide (Figure 1) (72, 73). CD8 T cell epitopes include peptides derived from preproinsulin $(44,46)$, IGRP (70), Zinc transporter 8 (74, 75), and glutamic acid decarboxylase 65 (Figure 1) (76). Of particular importance in both the NOD mouse model system and for translation to the human disease is a peptide derived from amino acids 10-23 of the insulin B chain (InsB10:23). This peptide is required for the development of autoimmune diabetes in the NOD mouse (45). Nakayama et al. determined that a single amino acid substitution in a TCR contact site for both CD4 and CD8 T cells conferred complete protection by altering a dominant immune target within the insulin protein (45). Similarly, we determined that insulin-specific $\mathrm{T}$ cell responses were critical in the spontaneous mouse model of diabetes (77). We demonstrated that blocking insulin-specific $\mathrm{T}$ cell responses could reverse and even cure diabetes in mice. In addition, re-establishing immune tolerance to proinsulin prevents diabetes onset in NOD mice, but re-establishing tolerance to $\mathrm{IGRP}_{206-214}$ does not prevent diabetes in NOD mice (78). Despite these fundamental discoveries, we still do not fully understand antigen hierarchy in T1D patients, likely because multiple different targets may be required for disease in different patients (79).

Exciting recent work from several groups has demonstrated the presence of neoantigens for diabetogenic CD4 $\mathrm{T}$ cells. These comprise hybrid peptides or combinations of amino acid sequences derived from two different secretory granule proteins or peptide sequences $(80,81)$. The frequency of $\mathrm{T}$ cell priming events against hybrid peptides during autoimmune pathogenesis is not clear in vivo; however, compelling evidence in vitro suggests that these cells may play an important role in T1D pathogenesis. It is thought that hybrid peptides are generated exclusively in beta cells and not in the thymus, thus representing "new" targets in the periphery. These targets could be viewed as foreign peptides eliciting a strong immune response. Recent reports also suggest that pancreatic neoantigens could arise from defective ribosomal insulin gene products (DRiPs), which are produced by metabolically stressed beta cells (82). Similarly to hybrid peptides, central tolerance to DRiPs generated by stressed beta cells would be lacking in the thymus. In the presence of inflammation and cell death, $\mathrm{T}$ cell responses to such neoantigens would develop in the periphery and could contribute to disease pathogenesis. Table 1 summarizes known autoantigens in T1D development in human subjects and NOD mice and if they are recognized by CD4 or CD8 $\mathrm{T}$ cells in the context of the appropriate HLA/MHC molecule.

\section{Mechanisms of Immune Tolerance}

There are four broad categories of immune tolerance that could protect beta cells from destruction by autoreactive T cells. First, negative selection during thymic development culls self-reactive $\mathrm{T}$ cells during $\mathrm{T}$ cell development. Due to this mechanism,
TABLE 1 | Beta cell secretory granule-derived auto antigens.

\begin{tabular}{|c|c|c|c|}
\hline Protein target & $\begin{array}{l}\text { NOD mouse } \\
\text { and/or human } \\
\text { T1D }\end{array}$ & $\begin{array}{l}\text { CD4 and/or } \\
\text { CD8 T cells }\end{array}$ & Reference \\
\hline (Pre)proinsulin & $\begin{array}{l}\text { Mouse and } \\
\text { human }\end{array}$ & CD4 and CD8 & $(36,44,46,78)$ \\
\hline Insulin & $\begin{array}{l}\text { Mouse and } \\
\text { human }\end{array}$ & CD4 and CD8 & $(44,45,76,83)$ \\
\hline $\begin{array}{l}\text { Defective ribosomal insulin } \\
\text { gene product }\end{array}$ & Human & CD8 & (82) \\
\hline Insulin hybrid peptides & $\begin{array}{l}\text { Mouse and } \\
\text { human }\end{array}$ & CD4 & $(80,81)$ \\
\hline GAD65 & $\begin{array}{l}\text { Mouse and } \\
\text { human }\end{array}$ & CD4 and CD8 & (84-88) \\
\hline ZnT8 & $\begin{array}{l}\text { Mouse and } \\
\text { human }\end{array}$ & CD4 and CD8 & $(74,75,89-92)$ \\
\hline Islet antigen-2 & Human & CD4 and CD8 & $(93-95)$ \\
\hline Phogrin & $\begin{array}{l}\text { Mouse and } \\
\text { human }\end{array}$ & CD4 & (96-99) \\
\hline Islet cell autoantigen 69 kDa & Human & CD4 & $(100-103)$ \\
\hline Chromogranin A & $\begin{array}{l}\text { Mouse and } \\
\text { human }\end{array}$ & CD4 and CD8 & $(71,104,105)$ \\
\hline Islet amyloid polypeptide & $\begin{array}{l}\text { Mouse and } \\
\text { human }\end{array}$ & CD4 and CD8 & $\begin{array}{c}(72,73,106 \\
107)\end{array}$ \\
\hline $\begin{array}{l}\text { Islet-specific glucose-6- } \\
\text { phosphatase catalytic } \\
\text { subunit-related protein }\end{array}$ & $\begin{array}{l}\text { Mouse and } \\
\text { human }\end{array}$ & CD4 and CD8 & $\begin{array}{c}(70,78,108 \\
109)\end{array}$ \\
\hline
\end{tabular}

autoreactive T cells generally do not survive thymic development. However, diabetes-associated MHC class I and II alleles facilitate the escape of self-reactive lymphocytes from the negative selection process. This escape could be due to several non-mutually exclusive reasons: low thymic expression of islet antigens (110), poor binding of native (non-transcriptionally modified) islet autoantigens to MHC I/II [as suggested in Ref. (111)], and $\mathrm{T}$ cell-intrinsic resistance to apoptosis (112) (Figure 1). GWAS studies link allelic variation at the insulin variable number tandem repeat (INS-VNTR) IDDM2 locus with the level of thymic insulin expression and disease development. Protective alleles of the IDDM2 diabetes susceptibility locus promote higher levels of insulin expression in the thymus, which would promote more robust negative selection of insulin-reactive $\mathrm{T}$ cells (113). In addition, mice genetically engineered to express lower levels of insulin in the thymus demonstrate correspondingly higher levels of peripheral $\mathrm{T}$ and $\mathrm{B}$ cell reactivity against insulin (110), and published work indicates that pancreatic lymph nodes of NOD mice contain higher than expected levels of insulin mRNA at 3-5 weeks of age (114). These observations suggest a direct link between the level of extra-pancreatic insulin expression and peripheral lymphocyte reactivity to insulin and point to ineffective negative selection in NOD mice and human patients. Second, immune ignorance occurs if an autoreactive lymphocyte survives thymic development, but does not encounter its cognate antigen in the periphery. The ignorance pathway appears to be an important method for maintenance of B cell tolerance (115). Additional evidence of autoantigen-specific $\mathrm{T}$ cell ignorance can be found in the MHC-matched T1D-resistant B6.g7 mouse model (116). 
A third mechanism of tolerance is a state of antigen-specific unresponsiveness called anergy. CD4 T cell anergy is defined as expression of folate receptor 4 and CD73 and hyporesponsiveness to TCR stimulation (117). While the majority of insulin-specific CD4 T cells in NOD mice are anergic, this form of tolerance is not sufficient o halt diabetes (Figure 1) (116). A fourth mode of immune tolerance relies on thymic-derived and peripheral regulatory CD4 $\mathrm{T}$ cells (Tregs) expressing the transcription factor Foxp3 (Figure 1). Foxp3 is the master regulator of Treg fate, stability, and suppressive capacity (118). Mutations in the Foxp3 locus (IPEX in humans and Scurfy in mice) lead to multiorgan autoimmunity and demonstrate a non-redundant role of Foxp3 in maintaining tolerance (118). Recent evidence demonstrates that the augmentation of Treg activity specifically within pancreatic islets may ameliorate diabetes pathogenesis in NOD mice (119). This result suggests that promoting Treg activity specifically within the pancreas may be beneficial in human T1D as well. In addition, Tregs can inhibit effector T cells specific for the same or "linked" peptides. "Linked suppression" refers to the ability of regulatory $\mathrm{T}$ cells to suppress activation of effector $\mathrm{T}$ cells interacting with the same antigen-presenting cell at the time of Treg-APC interaction. This concept was originally demonstrated by Davies et al. (120) and reviewed in Ref. (121) and has been shown to apply to the murine model of multiple sclerosis, experimental autoimmunity encephalomyelitis, as well (122). In addition, this mechanism has recently been shown to apply to a heart transplant model in mice, in which immune tolerance was induced to multiple distinct foreign MHC molecules (123). As such, we speculate that determination of "linked" peptides to promote CD4 T cell tolerance to islet allografts in autoimmune recipients represents a powerful opportunity to prevent islet allograft rejection in autoimmune recipients.

While several hundred protocols have prevented diabetes in NOD mice, very few of these have successfully reversed disease, and none have yet been translated to standard clinical practice $(124,125)$. Briefly, tolerance-promoting therapies have generally focused on inhibiting autoreactive $\mathrm{T}$ or B cells, decreasing inflammation prior to diabetes onset, or some combination of these approaches. In attempts to restore tolerance in the CD4 $\mathrm{T}$ cell compartment, we previously used whole insulin protein coupled to apoptotic cells through the chemical cross-linker ethylene carbodiimide, or ECDI (77). This approach reversed T1D in almost half of the treated mice. ECDI-coupled cells have been used in phase I safety trials for multiple sclerosis and have shown a desirable safety profile (Figure 1) (126). We predict that this approach could be tested for safety and efficacy in T1D. Adoptive transfer of regulatory CD4 $\mathrm{T}$ cells can halt diabetes pathogenesis in mice through inhibition of IFN- $\gamma$ production by islet-infiltrating CD4 and CD8 T cells and decreased islet infiltration by CD8 T cells (127). These findings were translated to the clinic, with encouraging results. Two separate research groups have demonstrated that deficiencies in IL-2 production (128) or the responsiveness of Treg cells to IL-2 (129) may be related to the development of autoimmune diabetes in NOD mice. Two separate groups have adoptively transferred autologous (selfderived) Tregs into new-onset T1D patients to enhance function of endogenous Tregs (Figure 1). A European group isolated and expanded Tregs from T1D patients (130) and then went on to demonstrate preservations of C-peptide in 8 of 12 subjects and reversal of new-onset T1D in 2 patients (131). In addition, a group at UCSF led by Bluestone and colleagues developed a protocol to expand Tregs from T1D patients (132) and then proved safety in phase I clinical trials (133). Several groups have established that Tregs can be isolated, expanded ex vivo in the presence of CD3/CD28 stimulation and IL-2, and adoptively transferred into patients (132-134). Transferred Tregs were detectable in blood up to 12 months later, remained phenotypically stable, and had the potential to influence diabetes pathogenesis. Both of these Treg adoptive transfer clinical trials utilized in vitro expanded Tregs, not Tregs specific for particular pancreatic target(s). It is not known if targeting particular autoantigens would provide additional protection compared to the current Treg transfer approach. Taken together, these recent clinical trials suggest that adoptive Treg therapy may help preserve residual beta cell mass in new-onset T1D patients. Whether this approach could prevent T1D onset in at-risk individuals is an open question and warrants future investigation.

\section{DIABETIC COMPLICATIONS INDICATING ISLET CELL REPLACEMENT}

Type 1 diabetes often results in large swings in blood glucose levels outside the normal physiologic range of $70-110 \mathrm{mg} / \mathrm{dl}$. Studies of 50-year Joslin Medalists indicate that individuals with T1D can live for many decades with minimal or no diabetic complications $(2,3)$. In addition, recent advances in fast-acting synthetic insulin analogs, continuous glucose level monitoring technology, and early attempts at developing pump-like systems to deliver glucagon suggest that individuals with T1D would continue to see improvements in diabetes management and therefore in quality of life. However, even with adequate clinical control of blood sugar levels, long-term diabetic complications can develop in individuals with T1D. In addition, despite the technical and clinical advances noted above, some individuals with T1D nonetheless have labile blood glucose level control and are susceptible to severe and life-threatening disease-related complications. These chronic complications can affect essentially every organ system and are particularly pronounced in the microvasculature. Diabetes, T1D and T2D combined, is the leading cause of adult blindness [diabetic retinopathy (135)] and end-stage renal failure [diabetic nephropathy (136)], as well as a leading cause of lowerleg amputations [diabetic peripheral neuropathy (137)] and heart disease [diabetic cardiomyopathy $(138,139)]$. Perhaps the most debilitating diabetic complication is hypoglycemic unawareness. This occurs when an individual with T1D is not aware their blood glucose levels are dangerously low $(<50 \mathrm{mg} / \mathrm{dl})$. This condition can result in seizures, diabetic coma, and, in the most severe cases, death. The development of hypoglycemia unawareness is thought to result from frequent, severe swings in blood glucose levels in some long-term T1D patients. Why hypoglycemia unawareness develops in some individuals but not others with long-term T1D is an open question. One possibility is that, over time, some T1D patients develop autoreactivity against glucagon-producing 
alpha cells. Glucagon-reactive CD8 T cells have been identified in NOD mice (140); therefore we speculate that some individuals with T1D may develop autoimmunity against alpha cells over time. Glucagon acts in opposition to insulin, promoting glycogen breakdown in the liver and therefore promoting increased blood glucose levels. If glucagon-derived peptides are associated with inflammation and cell death within the pancreas, existing autoreactive $\mathrm{T}$ cells could become primed in pancreas-draining lymph nodes, proliferate, and mediate destruction of glucagonproducing cells. In fact, there is emerging evidence that a small proportion of T1D patients develop antiglucagon antibodies (140). Another possibility is that destruction of autonomic innervation within pancreatic islets (141) leads to impaired communication with the hypothalamus, so that glucagon is not produced when signals are present based on blood glucose levels. If autonomic innervation of pancreatic islets is perturbed in individuals with $\mathrm{T} 1 \mathrm{D}$, the consequence could be a breakdown in communication with the hypothalamus. Interestingly, some T1D but not T2D subjects develop autoantibodies against the neuroendocrine protein tetraspanin7 from sympthatheic nerves within islets (142). In some patients with severe hypoglycemia, both of these scenarios, and others, could lead to impaired glucagon responses to hypoglycemia. Whole pancreas and isolated pancreatic islet transplantation are options to restore blood glucose level homeostasis for individuals with hypoglycemia unawareness. There are two potential sources of pancreatic beta cells for islet replacement, cadaveric (deceased) donors and iPS-derived beta cells (143), both of which are discussed below.

\section{ISLET GRAFT ALLOIMMUNITY}

\section{Islet Replacement Strategies}

The current clinical strategy to replace the lost beta cell function is through whole pancreas or isolated pancreatic islet transplantation from genetically unrelated cadaveric donors. Because donors are limited, currently only T1D patients with hypoglycemia unawareness are considered for transplantation. This has created great interest in cell culture methods to produce large quantities of insulin-producing cells for transplantation. After more than 10 years of development, the Melton laboratory became the first group to develop a reproducible protocol for iPS conversion to insulin-producing beta cells (143), quickly followed by several other groups (144-146). However, these methods are not yet suitable for large-scale production of patient-specific iPS-beta cells for transplantation studies since individuals require several hundred thousand individual pancreatic islets. Furthermore, a critical limiting factor of a "universal donor" beta cell line is conventional transplant recognition, described below. In addition, unlike whole pancreas or isolated islet transplantation, iPS-beta cells do not replace the lost alpha cell function. Until these challenges are addressed, transplantation from a cadaveric donor will likely remain the preferred approach in combination with immune suppression $(147,148)$. A recent phase III clinical trial demonstrated improved glycemic control in islet transplant recipients following multisite standardized processing protocols $(149,150)$. As less beta cell-toxic immune suppression treatments are developed, we can expect transplant function and long-term survival to continue to improve. In the absence of these treatments, transplanted beta cells in autoimmune recipient patients would be subject to at least two categories of $\mathrm{T}$ cell responses: (a) autoimmune (islet-specific) responses by $\mathrm{T}$ cells $(151,152)$, and (b) conventional anti-transplant-reactive $\mathrm{T}$ cell responses. However, current immune suppression treatments do not promote immune tolerance as described above, must be continued indefinitely after transplantation, and can render the transplant recipient vulnerable to cancer and infectious agents. Therefore, transplant-specific tolerance-promoting treatments are a highly sought after goal in the islet transplantation field.

An alternative to replacing the lost beta cell mass would be to stimulate beta cell regeneration. Beta cell regeneration is based on the premise that if autoreactive $\mathrm{T}$ cells are removed or inhibited, existing beta cells could proliferate, alpha cells could convert into beta cells, or islet-resident stem cell populations could proliferate and differentiate into beta cells. There is little experimental evidence to support these suppositions to date. Beta cells are exceptionally metabolically active, continuously producing insulin secretory granules. The less beta cell mass is available to produce insulin, the higher the metabolic stress is on each individual islet. Therefore, the ability to regenerate beta cells from existing beta cells could be a significant hurdle. Another theoretical option to replace lost beta cell mass is to promote trans-differentiation of existing alpha cells into beta cells. Recent evidence from Kim's laboratory at Stanford suggests that alpha cell conversion to beta cells may be feasible (153). However, even if beta cell replacement, alpha cell trans-differentiation, or beta cell regeneration succeed, these strategies do not address the deficiency in alpha cell glucagon production, which precipitates hypoglycemia unawareness, and as such do not represent a complete treatment for this lifethreatening diabetic complication on its own. Therefore, whole islet transplantation will remain the clinical standard-of-care over beta cell replacement until these concerns can be fully addressed.

\section{Concurrent Autoimmune and Alloimmune Pathogenesis}

There are two separate immune recognition pathways leading to the destruction of transplanted beta cells in the autoimmune recipient. As mentioned above, the first is autoimmunity due to antigen-specific memory $\mathrm{T}$ cells. Regardless of the source of beta cells transplanted into an individual with T1D, autoimmune $\mathrm{T}$ cells would target cells producing insulin and must be inhibited or removed to facilitate long-term transplant function (154). In contrast, autoreactive T cell targeting of a kidney transplant in a diabetic individual would not likely occur, because there would be no pre-existing kidney-specific memory $\mathrm{T}$ cells (154). Alloimmunity is the second major concern leading to the destruction of transplanted beta cells. Transplant-reactive or alloreactive $\mathrm{T}$ cell responses can target the genetic differences between the transplant donor and recipient (155). This category of immune response occurs against any organ or tissue transplant, in any individual, regardless of autoimmune disease status (156). Importantly, these transplant-specific responses focus primarily on the HLA molecule of the human transplant or MHC in mouse. 
HLA molecules are the most polymorphic loci in the human genome, and each individual expresses multiple alleles of both class I and class II HLA (154-156). All the genetic differences in both alleles are potential antigens and could be targeted by $\mathrm{T}$ cells in transplant recipients. The differences in HLA class I are targeted by recipient CD $8 \mathrm{~T}$ cells, and the differences in HLA class II are targeted by recipient CD4 T cells (156). Ironically, genetic diversity in HLA promotes diverse T cell responses to the same pathogen in different individuals, but unfortunately these genetic differences also promote strong $\mathrm{T}$ cell responses against any transplanted organ or tissue. In this section, we describe transplant recognition and alloimmunity separately from autoimmunity.

\section{Transplant Recognition: Direct and Indirect Pathways}

Donor-derived MHC (or HLA) molecules are the most prevalent transplant-derived antigen seen by the immune system of a transplant recipient. Transplant recipient $\mathrm{T}$ cells can interact with donor MHC molecules in two ways termed direct and indirect recognition (157). Direct allorecognition results from T cell interaction with donor MHC (plus some peptide loaded in MHC), whereas indirect allorecognition results from $\mathrm{T}$ cell interactions with recipient $\mathrm{MHC}$ (plus peptide derived from donor $\mathrm{MHC}$, or any other transplant-derived protein). It is estimated that $1-10 \%$ of CD8 T cells or CD4 T cells will spontaneously respond to allogeneic MHC I or MHC II, respectively [reviewed in Ref. (158)]. In contrast, we hypothesize that the indirect precursor frequency is even smaller. In support of this hypothesis, recent evidence indicates that only $10 \%$ of allograft-reactive CD4 T cells in a mouse model of cardiac allograft rejection are indirect, while the remaining $90 \%$ are direct alloreactive CD4 T cells (159). Due to the higher precursor frequency for direct allorecognition than indirect allorecognition [reviewed in Ref. (157)], immune suppression protocols appear to hold direct alloreactivity in check. However, indirect recognition, which leads to antibody formation, CD4 $\mathrm{T}$ cell reactivity, and complement activation, is not completely inhibited using current immune suppression treatment regiments, as shown by complement deposition and antibody formation in chronic rejection models (160).

Importantly, both CD4 and CD8 T cells in the recipient can interact with donor $\mathrm{MHC}$ through either the direct or indirect pathway. The frequency and physiologic relevance of direct and indirect allorecognition varies with the nature of the transplanted organ or tissue. For islet allograft recognition, donor MHC class $\mathrm{I}$ and direct interaction with recipient CD8 T cells is a highfrequency event, because all cells in the graft express MHC class I. Since beta cells do not express MHC class II at baseline (161), direct recognition via CD4 T cells may not be as high frequency of an event. However, recent evidence suggests that beta cells may express MHC class II following T cell infiltration (161), which suggests that direct alloreactive CD4 T cells may be critical for anti-islet allograft responses. In contrast, indirect allorecognition by CD8 $\mathrm{T}$ cells must be therapeutically addressed to prevent islet allograft rejection (see below discussion of CD154 blockade therapy). Table 2 summarizes the roles of direct and indirect CD4 and CD8 $\mathrm{T}$ cells in islet allograft rejection in the NOD mouse model.

\section{Islet Allograft Tolerance in Non- Autoimmune Diabetic Mice}

Unfortunately, islet transplants are subject to both autoimmune disease recurrence and allograft recognition in T1D mice and humans. To remove autoimmunity as a confounding variable from islet transplant tolerance studies, several labs have made use of the free radical generator streptozotocin (STZ) (165-167). STZ induces diabetes due to the relative lack of free radical scavenging enzymes expressed in pancreatic beta cells relative to other cell types (168). Following induction of diabetes with STZ, mice can be transplanted with allogeneic (MHC-disparate) pancreatic islets and treated with candidate transplant tolerance-promoting therapies. In experiments using non-autoimmune diabetic mice, untreated recipients serve as control groups to determine time to normal allograft rejection.

Multiple different general immune suppressive therapies have been tested in preclinical mouse models and are used clinically (168). These therapies can include anti-CD3, antithymocyte globulin, calcineurin inhibitors, mTOR inhibitors, tacrolimus, or mycophenolate mofetil (169). Interestingly, one of the tolerance-promoting protocols, which reversed diabetes, ECDI-coupled splenocytes, can also promote islet allograft tolerance in non-autoimmune mice (170). Of particular interest, monoclonal antibodies to block $\mathrm{T}$ cell co-stimulation (or signal 2 ) have been tested by several groups $(165,171)$. For example, short-term monoclonal antibody therapy directed against the T cell-expressed co-stimulation molecule CD154 (CD40L) has been shown by several groups $(165,171)$ to induce long-term

TABLE 2 | Islet allograft recognition pathways and likely players in rejection in autoimmune diabetic recipients.

\begin{tabular}{|c|c|c|c|c|c|c|c|}
\hline $\begin{array}{l}\text { Direct or } \\
\text { indirect }\end{array}$ & T cells & Target & $\begin{array}{l}\text { Precursor frequency } \\
\text { in recipients }\end{array}$ & $\begin{array}{l}\text { Fold expansion } \\
\text { posttransplant }\end{array}$ & $\begin{array}{l}\text { Sufficient for } \\
\text { rejection? }\end{array}$ & $\begin{array}{l}\text { Required for } \\
\text { rejection? }\end{array}$ & Reference \\
\hline Direct & $\begin{array}{l}\text { CD4 } \\
\text { T cells }\end{array}$ & Donor MHC II + transplant-derived peptide & $\begin{array}{l}0.1-10 \% \text { versus individual } \\
\text { donor } \mathrm{MHC}\end{array}$ & $10-100$ & Yes & No & $(162-164)$ \\
\hline Direct & $\begin{array}{l}\text { CD8 } \\
\text { T cells }\end{array}$ & Donor MHC I + transplant-derived peptide & $\begin{array}{l}0.1-10 \% \text { versus individual } \\
\text { donor } \mathrm{MHC}\end{array}$ & $10-100$ & Yes & No & $(162-164)$ \\
\hline Indirect & $\begin{array}{l}\text { CD4 } \\
\text { T cells }\end{array}$ & $\begin{array}{l}\text { Donor-derived peptide loaded in recipient } \\
\text { MHC ॥ }\end{array}$ & Less than 1 in $1,000,000$ & $>100$ & Yes & Appears likely & $(162-164)$ \\
\hline Indirect & $\begin{array}{l}\text { CD8 } \\
\text { T cells }\end{array}$ & $\begin{array}{l}\text { Donor-derived peptide loaded in recipient } \\
\mathrm{MHC} \mathrm{I}\end{array}$ & Less than 1 in $1,000,000$ & $>100$ & Yes & Appears not & $(162-164)$ \\
\hline
\end{tabular}


(>100 days) islet allograft tolerance across full MHC mismatch donor/recipient pairs (e.g., BALB/c islets transplanted into STZtreated $\mathrm{B} 6$ male mice). This tolerance resides in the CD4 $\mathrm{T}$ cell compartment and can be transferred from treated and tolerant mice to naive mice (165). It is controversial whether this therapy induces allo-specific regulatory $\mathrm{T}$ cells de novo [suggested by Ferrer et al. (172)] or inhibits reactivity of naive alloreactive CD8 $\mathrm{T}$ cells through killing mediated by NK cells (173), or if these effects are simultaneous. In addition, the combination of antiCD154 antibody with other therapies has been highly efficacious, in particular LFA-1 blockade. LFA-1 (CD11a) is an adhesion molecule expressed on most leukocytes, in particular on neutrophils, macrophages, and activated T cells. LFA-1 inhibition appears to delay and/or prevent islet allograft rejection as a single therapy. Similar to anti-CD154-induced transplant tolerance, uniform (100\% of mice), long-term ( $>100$ days) tolerance induced by the combination therapy of LFA-1 blockade and CD154 blockade resided in the CD4 $\mathrm{T}$ cell compartment and was serially transferable to multiple islet allograft recipients (165). In summary, STZ-induced diabetes represents a useful, non-autoimmune model system to test candidate islet allograft tolerance-promoting therapies. However, the end goal is to induce islet tolerance in autoimmune recipients, such as the NOD mouse.

In islet transplantation studies, "indirect" (recipient MHCrestricted) alloreactive CD4 $\mathrm{T}$ cells are key perpetrators of islet allograft rejection (174). As such, we hypothesize that cotransfer of islet antigen-specific Tregs at the time of islet transplantation would inhibit alloreactive $\mathrm{T}$ cell responses. Indeed, immune tolerance to antigen-presenting cell-depleted islet allografts in non-autoimmune mice requires CD4 T cells in transplant recipient mice (175). An alternative approach is to promote expression of $\mathrm{T}$ cell inhibitory receptor ligands on beta cells prior to transplantation (Figure 1). One example of this approach is beta cell expression of Fas ligand, which when combined with the immune suppressive drug rapamycin generated Tregs in recipient mice (176). Another example of this approach is a recent report which demonstrated that enforced beta cell-intrinsic PD-L1 and CTLA4 expression significantly delayed islet allograft rejection in NOD mice (177). In conclusion, whether autoimmunity or alloimmunity drives islet transplant rejection, generation, or adoptive transfer of Tregs or pre-arming transplanted beta cells with co-inhibitory molecules represent two distinct strategies to protect beta cells.

\section{Potential Role for Regulatory CD4 T Cells in the Autoimmune Recipient of an Islet Allograft}

Importantly, regulatory CD4 Foxp $3^{+} \mathrm{T}$ cells engage peptides through the indirect antigen recognition pathway. Therefore, therapies that promote the development of transplant-specific Tregs are highly desirable. One long-term goal of the islet transplantation and autoimmunity field is to either deplete "indirect" autoreactive CD4 T cells or re-educate these CD4 T cells to become Foxp $3^{+}$regulatory CD4 $\mathrm{T}$ cells, while also generating additional "indirect" Tregs specific for transplant-derived antigens. Based on the above considerations for beta cell MHC II expression in the inflamed transplant recipient, we hypothesize that regulatory CD4 T cells specific for donor MHC II would prolong islet allograft survival. In addition, we hypothesize that conventional self-reactive and "indirect" CD4 T cells, which recognize autoantigens through the transplant recipient's $\mathrm{MHC}$ class II molecule, would prolong graft survival. In combination, we speculate that adoptive transfer of both autoantigen-specific "indirect" Tregs as well as transplant MHC II-specific "direct" Tregs would synergize to significantly prolong islet allograft survival in autoimmune recipients.

\section{Failure of Islet Transplant Tolerance in the NOD Mouse}

Laboratories at the Barbara Davis Center (31), Vanderbilt (178), Harvard (179), University of Massachusetts (180), University of North Carolina (181), the University of Miami (182), and the St. Vincent's Institute in Melbourne (78) have utilized the NOD mouse as a model system to study both autoimmune disease recurrence (rejection of NOD-background islets) or islet allograft rejection (rejection of islet from genetically unrelated donor strains including $\mathrm{B} 6, \mathrm{C} 3 \mathrm{H})$. Due to its autoimmune disease status, the diabetic NOD female islet transplant recipient is a difficult, but clinically relevant model to test islet transplant tolerance-promoting therapies. Several studies have demonstrated the requirement for both CD4 T cells and CD8 T cells in diabetes recurrence in NOD mice $(183,184)$. Less data are available in the islet allograft scenario in NOD mice. Due to the sheer number of pancreatic islets required to reverse hyperglycemia and rapid T cell-mediated transplant rejection, diabetic female NOD mice are not frequently used to test transplant tolerance-promoting therapies.

The NOD mouse is an extremely stringent model to test transplant tolerance-promoting therapies. There are vanishingly few examples of long-term transplant tolerance in NOD mice. In particular, the combination of CD154 and LFA-1 in B6 mice resulted in long-term tolerance $(180,185)$. It is controversial whether this stringency results from resistance to therapeutic intervention in the autoimmune primed/memory $\mathrm{T}$ cell compartment, the alloreactive T cell response in NOD mice, or both. Mouse models and human clinical reports have suggested that autoimmune $\mathrm{T}$ cells are less susceptible to conventional immunosuppression $(151,185)$. In addition and in parallel, data from NOD mice support the existence of an accelerated and therapyresistant anti-allograft $\mathrm{T}$ cell response (162). Additional studies in the Bio Breeder rat further suggested that autoimmune $\mathrm{T}$ cells are strongly impervious to tolerance-promoting therapy in this animal model of T1D, whereas the anti-allograft response can be made tolerant (186-189). These differences between models, and a lack of peptide-MHC II reagents to separately track both autoreactive and alloreactive CD4 T cells in the same transplant recipient mouse, lead to a lack of consensus in the field and an incomplete understanding of auto- and allo- $\mathrm{T}$ cell tolerance, in particular when both immune responses occur simultaneously.

While global immune suppressive treatments promote survival of transplanted beta cells [with the exception of calcineurin inhibitors, which are toxic to beta cells (190)], it is challenging to interpret effects of immune-modulatory therapies on specific $\mathrm{T}$ cell populations. Clinically, in the autoimmune recipient of 
pancreatic islets, there are at least two concurrent immune responses. As such, a major limiting factor in this analysis is the quality and availability of reagents to reliably and separately track autoreactive and alloreactive $\mathrm{T}$ cell responses in human patients. Lack of validated reagents to monitor these responses longitudinally in clinical samples presents a major challenge to interpret therapeutic effects on recurrent autoimmunity versus anti-allograft responses. Lack of reagents to separately assess these two categories of $\mathrm{T}$ cell responses in the NOD mouse prevents the development of reagents to preferentially influence either category of $\mathrm{T}$ cell response in the preclinical or clinical setting.

\section{CONCLUDING REMARKS}

To prevent diabetes onset in the NOD mouse or at-risk human patients, several goals must be achieved. The genetics of T1D risks are well established, but the field lacks a comprehensive panel of peptide-HLA II tetramers to specifically track diseaseassociated CD4 T cell populations. Several groups (191-193), including our own (194), are working to fill this gap. Reagents to track key pathogenic CD4 T cells, perhaps including hybrid peptide-specific or DRiP-specific CD4 and CD8 T cells, are being developed and validated for clinical use. In addition, predictive biomarkers to measure not only the presence of these autoreactive $\mathrm{T}$ cells but also their activation status should be a focus of attention. Real-time monitoring of the activation status of ratelimiting autoreactive $\mathrm{T}$ cells is required to measure the efficacy of any tolerance-promoting therapy. Finally, to establish beta cell protection, measurements of beta cell function are required, in combination with assessment of autoreactive T cell biology. Non-invasive imaging methods represent one option $(195,196)$, but require specialized imaging technology and may not have sufficient sensitivity. More recently, methods such as high-sensitivity C-peptide assays $(46,197)$ and quantification of demethylated insulin DNA in the circulation $(198,199)$ could accomplish this beta cell health surveillance goal.

Despite our understanding of diabetes pathogenesis and ever-improving clinical care for individuals with T1D, some individuals develop debilitating diabetic complications that necessitate whole pancreas or isolated islet transplantation. In the autoimmune recipient, two categories of $\mathrm{T}$ cell responses must be prevented or inhibited to promote long-term transplant function. Both memory autoimmune $\mathrm{T}$ cell responses and

\section{REFERENCES}

1. Atkinson MA, Eisenbarth GS, Michels AW. Type 1 diabetes. Lancet (2014) 383(9911):69-82. doi:10.1016/S0140-6736(13)60591-7

2. Keenan HA, Sun JK, Levine J, Doria A, Aiello LP, Eisenbarth G, et al. Residual insulin production and pancreatic $\beta$-cell turnover after 50 years of diabetes: Joslin Medalist Study. Diabetes (2010) 59(11):2846-53. doi:10.2337/db10-0676

3. Sun JK, Keenan HA, Cavallerano JD, Asztalos BF, Schaefer EJ, Sell DR, et al. Protection from retinopathy and other complications in patients with type 1 diabetes of extreme duration: the Joslin 50-year Medalist Study. Diabetes Care (2011) 34(4):968-74. doi:10.2337/dc10-1675

4. Rodriguez-Calvo T, Ekwall O, Amirian N, Zapardiel-Gonzalo J, von Herrath MG. Increased immune cell infiltration of the exocrine pancreas: a possible contribution to the pathogenesis of type 1 diabetes. Diabetes (2014) 63(11):3880-90. doi: $10.2337 / \mathrm{db} 14-0549$ nascent $\mathrm{T}$ cell responses against polymorphic MHC molecules occur after pancreas, islets, or iPS-beta cell replacement in T1D individuals. Therefore, a thorough understanding of not only autoimmune pathogenesis but also transplant recognition is required to develop methods to protect transplanted beta cells in autoimmune individuals. Intriguingly, Foxp $3{ }^{+} \mathrm{CD} 4$ regulatory $\mathrm{T}$ cells may represent a path toward developing antigen-specific tolerance in both autoimmunity and transplant recognition. As such, immunotherapies that promote the development of regulatory CD4 T cells in both autoimmune models and transplantation models are highly desirable.

Multiple challenges remain to achieve the elusive goal of preventing islet transplant rejection in autoimmune recipients. Chief among these is to more specifically define the roles of CD4 and CD8 $\mathrm{T}$ cells and to determine whether autoimmunity or alloimmunity represents the higher barrier to beta cell transplant survival. Additional challenges to establishing islet allograft tolerance in the autoimmune recipient include (a) determining whether removing MHC from islet allografts would delay transplant rejection, (b) investigating if there is overlap of autoimmunity and alloreactivity on the individual T cell level, as has been shown for viral memory and transplant rejection $(200,201),(c)$ understanding if an MHC-matched "universal donor" beta cell line would avoid alloimmune $\mathrm{T}$ cell responses, (d) determining if beta cells can be induced to express proteins that would protect a transplant, and (e) developing reagents to track "direct" alloreactivity (against donor MHC). We and others are working to determine answers to these and other critical questions. With coordinated work by many dedicated individuals, we anticipate further advancements in our understanding of autoimmune pathogenesis, beta cell biology, and transplant recognition.

\section{AUTHOR CONTRIBUTIONS}

ALB, TM, and BTF wrote and edited the review article. TM and BTF created the model figure.

\section{FUNDING}

BF is supported by NIH R01 AI106791, P01 AI35296, U24 AI118635, and Regenerative Medicine of Minnesota RMM \#11215 TR002. AB is supported by NIH T32DK007203. TM is supported by the Frieda Martha Kunze Fellowship.

5. Pathiraja V, Kuehlich JP, Campbell PD, Krishnamurthy B, Loudovaris T, Coates PT, et al. Proinsulin-specific, HLA-DQ8, and HLA-DQ8-transdimerrestricted CD4+ T cells infiltrate islets in type 1 diabetes. Diabetes (2015) 64(1):172-82. doi:10.2337/db14-0858

6. Soeldner JS, Tuttleman M, Srikanta S, Ganda OP, Eisenbarth GS. Insulindependent diabetes mellitus and autoimmunity: islet-cell autoantibodies, insulin autoantibodies, and beta-cell failure. N Engl J Med (1985) 313(14):893-4. doi:10.1056/NEJM198510033131417

7. Eisenbarth GS. Type I diabetes mellitus. A chronic autoimmune disease. $N$ Engl J Med (1986) 314(21):1360-8. doi:10.1056/NEJM198605223142106

8. Zhang L, Gianani R, Nakayama M, Liu E, Kobayashi M, Baschal E, et al. Type 1 diabetes: chronic progressive autoimmune disease. Novartis Found Symp (2008) 292:85-94; discussion 94-8, 122-9, 202-3. doi:10.1002/9780470697405.ch7

9. Sutherland DE, Goetz FC, Sibley RK. Recurrence of disease in pancreas transplants. Diabetes (1989) 38(Suppl 1):85-7. doi:10.2337/diab.38.1.S85 
10. Coppieters KT, Dotta F, Amirian N, Campbell PD, Kay TW, Atkinson MA, et al. Demonstration of islet-autoreactive CD8 T cells in insulitic lesions from recent onset and long-term type 1 diabetes patients. J Exp Med (2012) 209(1):51-60. doi:10.1084/jem.20111187

11. Sarikonda G, Pettus J, Phatak S, Sachithanantham S, Miller JF, Wesley JD, et al. CD8 T-cell reactivity to islet antigens is unique to type 1 while CD4 T-cell reactivity exists in both type 1 and type 2 diabetes. J Autoimmun (2014) 50:77-82. doi:10.1016/j.jaut.2013.12.003

12. Rodriguez-Calvo T, Suwandi JS, Amirian N, Zapardiel-Gonzalo J, Anquetil F, Sabouri S, et al. Heterogeneity and lobularity of pancreatic pathology in type 1 diabetes during the prediabetic phase. J Histochem Cytochem (2015) 63(8):626-36. doi:10.1369/0022155415576543

13. Atkinson MA. The pathogenesis and natural history of type 1 diabetes. Cold Spring Harb Perspect Med (2012) 2(11). doi:10.1101/cshperspect.a007641

14. Pietropaolo M, Towns R, Eisenbarth GS. Humoral autoimmunity in type 1 diabetes: prediction, significance, and detection of distinct disease subtypes. Cold Spring Harb Perspect Med (2012) 2(10). doi:10.1101/cshperspect.a012831

15. Pociot F, Lernmark A. Genetic risk factors for type 1 diabetes. Lancet (2016) 387(10035):2331-9. doi:10.1016/S0140-6736(16)30582-7

16. Thayer TC, Delano M, Liu C, Chen J, Padgett LE, Tse HM, et al. Superoxide production by macrophages and T cells is critical for the induction of autoreactivity and type 1 diabetes. Diabetes (2011) 60(8):2144-51. doi:10.2337/ db10-1222

17. Padgett LE, Anderson B, Liu C, Ganini D, Mason RP, Piganelli JD, et al. Loss of NOX-derived superoxide exacerbates diabetogenic CD4 T-cell effector responses in type 1 diabetes. Diabetes (2015) 64(12):4171-83. doi:10.2337/ db15-0546

18. Makino S, Kunimoto K, Muraoka Y, Mizushima Y, Katagiri K, Tochino Y. Breeding of a non-obese, diabetic strain of mice. Jikken Dobutsu (1980) 29(1):1-13.

19. Anderson MS, Bluestone JA. The NOD mouse: a model of immune dysregulation. Annu Rev Immunol (2005) 23:447-85. doi:10.1146/annurev.immunol. 23.021704.115643

20. Mullen Y. Development of the nonobese diabetic mouse and contribution of animal models for understanding type 1 diabetes. Pancreas (2017) 46(4):455-66. doi:10.1097/MPA.0000000000000828

21. von Herrath MG, Homann D, Gairin JE, Oldstone MB. Pathogenesis and treatment of virus-induced autoimmune diabetes: novel insights gained from the RIP-LCMV transgenic mouse model. Biochem Soc Trans (1997) 25(2):630-5. doi:10.1042/bst0250630

22. Kurts C, Heath WR, Carbone FR, Kosaka H, Miller JF. Cross-presentation of self antigens to CD8+ T cells: the balance between tolerance and autoimmunity. Novartis Found Symp (1998) 215:172-81; discussion 181-90.

23. Apostolou I, Von Boehmer H. The TCR-HA, INS-HA transgenic model of autoimmune diabetes: limitations and expectations. JAutoimmun (2004) 22(2):111-4. doi:10.1016/j.jaut.2003.10.005

24. Van Belle TL, Taylor P, von Herrath MG. Mouse models for type 1 diabetes. Drug Discov Today Dis Models (2009) 6(2):41-5. doi:10.1016/j.ddmod.2009.03.008

25. Mora C, Wong FS, Chang $\mathrm{CH}$, Flavell RA. Pancreatic infiltration but not diabetes occurs in the relative absence of MHC class II-restricted CD4 T cells: studies using NOD/CIITA-deficient mice. J Immunol (1999) 162(8):4576-88.

26. Serreze DV, Leiter EH, Christianson GJ, Greiner D, Roopenian DC. Major histocompatibility complex class I-deficient NOD-B2mnull mice are diabetes and insulitis resistant. Diabetes (1994) 43(3):505-9. doi:10.2337/ diabetes.43.3.505

27. Yang M, Charlton B, Gautam AM. Development of insulitis and diabetes in B cell-deficient NOD mice. J Autoimmun (1997) 10(3):257-60. doi:10.1006/ jaut.1997.0128

28. Noorchashm H, Noorchashm N, Kern J, Rostami SY, Barker CF, Naji A. B-cells are required for the initiation of insulitis and sialitis in nonobese diabetic mice. Diabetes (1997) 46(6):941-6. doi:10.2337/diabetes.46.6.941

29. Zucchelli S, Holler P, Yamagata T, Roy M, Benoist C, Mathis D. Defective central tolerance induction in NOD mice: genomics and genetics. Immunity (2005) 22(3):385-96. doi:10.1016/j.immuni.2005.01.015

30. Wicker LS, Appel MC, Dotta F, Pressey A, Miller BJ, DeLarato NH, et al. Autoimmune syndromes in major histocompatibility complex (MHC) congenic strains of nonobese diabetic (NOD) mice. The NOD MHC is dominant for insulitis and cyclophosphamide-induced diabetes. JExp Med (1992) 176(1):67-77. doi:10.1084/jem.176.1.67
31. Wang Y, Hao L, Gill RG, Lafferty KJ. Autoimmune diabetes in NOD mouse is L3T4 T-lymphocyte dependent. Diabetes (1987) 36(4):535-8. doi:10.2337/ diabetes.36.4.535

32. Shizuru JA, Taylor-Edwards C, Banks BA, Gregory AK, Fathman CG. Immunotherapy of the nonobese diabetic mouse: treatment with an antibody to T-helper lymphocytes. Science (1988) 240(4852):659-62. doi:10.1126/ science. 2966437

33. Hutchings P, O'Reilly L, Parish NM, Waldmann H, Cooke A. The use of a non-depleting anti-CD4 monoclonal antibody to re-establish tolerance to beta cells in NOD mice. Eur J Immunol (1992) 22(7):1913-8. doi:10.1002/ eji.1830220735

34. Katz JD, Benoist C, Mathis D. T helper cell subsets in insulin-dependent diabetes. Science (1995) 268(5214):1185-8. doi:10.1126/science.7761837

35. Arif S, Tree TI, Astill TP, Tremble JM, Bishop AJ, Dayan CM, et al. Autoreactive $\mathrm{T}$ cell responses show proinflammatory polarization in diabetes but a regulatory phenotype in health. J Clin Invest (2004) 113(3):451-63. doi:10.1172/ JCI19585

36. Michels AW, Landry LG, McDaniel KA, Yu L, Campbell-Thompson M, Kwok WW, et al. Islet-derived CD4 T cells targeting proinsulin in human autoimmune diabetes. Diabetes (2017) 66(3):722-34. doi:10.2337/db16-1025

37. Gómez-Touriño I, Simón-Vázquez R, Alonso-Lorenzo J, Arif S, CalviñoSampedro C, González-Fernández Á, et al. Characterization of the autoimmune response against the nerve tissue $S 100$ beta in patients with type 1 diabetes. Clin Exp Immunol (2015) 180(2):207-17. doi:10.1111/cei.12572

38. Arif S, Moore F, Marks K, Bouckenooghe T, Dayan CM, Planas R, et al. Peripheral and islet interleukin-17 pathway activation characterizes human autoimmune diabetes and promotes cytokine-mediated betacell death. Diabetes (2011) 60(8):2112-9. doi:10.2337/db10-1643

39. Bellemore SM, Nikoopour E, Schwartz JA, Krougly O, Lee-Chan E, Singh B. Preventative role of interleukin-17 producing regulatory T helper type 17 (Treg 17) cells in type 1 diabetes in non-obese diabetic mice. Clin Exp Immunol (2015) 182(3):261-9. doi:10.1111/cei.12691

40. Babon JA, DeNicola ME, Blodgett DM, Crèvecoeur I, Buttrick TS, Maehr R, et al. Analysis of self-antigen specificity of islet-infiltrating T cells from human donors with type 1 diabetes. Nat Med (2016) 22(12):1482-7. doi:10.1038/ nm.4203

41. Trivedi P, Graham KL, Krishnamurthy B, Fynch S, Slattery RM, Kay TW, et al. Perforin facilitates beta cell killing and regulates autoreactive CD8+ T-cell responses to antigen in mouse models of type 1 diabetes. Immunol Cell Biol (2016) 94(4):334-41. doi:10.1038/icb.2015.89

42. DiLorenzo TP, Graser RT, Ono T, Christianson GJ, Chapman HD, Roopenian DC, et al. Major histocompatibility complex class I-restricted $\mathrm{T}$ cells are required for all but the end stages of diabetes development in nonobese diabetic mice and use a prevalent $\mathrm{T}$ cell receptor alpha chain gene rearrangement. Proc Natl Acad Sci U S A (1998) 95(21):12538-43. doi:10.1073/pnas.95.21.12538

43. Hamilton-Williams EE, Palmer SE, Charlton B, Slattery RM. Beta cell MHC class I is a late requirement for diabetes. Proc Natl Acad Sci U S A (2003) 100(11):6688-93. doi:10.1073/pnas.1131954100

44. Wong FS, Karttunen J, Dumont C, Wen L, Visintin I, Pilip IM, et al. Identification of an MHC class I-restricted autoantigen in type 1 diabetes by screening an organ-specific cDNA library. Nat Med (1999) 5(9):1026-31. doi:10.1038/12465

45. Nakayama M, Abiru N, Moriyama H, Babaya N, Liu E, Miao D, et al. Prime role for an insulin epitope in the development of type 1 diabetes in NOD mice. Nature (2005) 435(7039):220-3. doi:10.1038/nature03523

46. Roep BO, Solvason N, Gottlieb PA, Abreu JRF, Harrison LC, Eisenbarth GS, et al. Plasmid-encoded proinsulin preserves C-peptide while specifically reducing proinsulin-specific CD8(+) T cells in type 1 diabetes. Sci Transl Med (2013) 5(191):191ra82. doi:10.1126/scitranslmed.3006103

47. Suk K, Kim S, Kim YH, Kim KA, Chang I, Yagita H, et al. IFN-gamma/TNFalpha synergism as the final effector in autoimmune diabetes: a key role for STAT1/IFN regulatory factor-1 pathway in pancreatic beta cell death. J Immunol (2001) 166(7):4481-9. doi:10.4049/jimmunol.166.7.4481

48. Chen J, Grieshaber S, Mathews CE. Methods to assess beta cell death mediated by cytotoxic T lymphocytes. J Vis Exp (2011) 52. doi:10.3791/2724

49. Calderon B, Suri A, Pan XO, Mills JC, Unanue ER. IFN-gamma-dependent regulatory circuits in immune inflammation highlighted in diabetes. J Immunol (2008) 181(10):6964-74. doi:10.4049/jimmunol.181.10.6964 
50. Bender C, Christen S, Scholich K, Bayer M, Pfeilschifter JM, Hintermann E, et al. Islet-expressed CXCL10 promotes autoimmune destruction of islet isografts in mice with type 1 diabetes. Diabetes (2017) 66(1):113-26. doi:10.2337/ db16-0547

51. Sarkar SA, Lee CE, Victorino F, Nguyen TT, Walters JA, Burrack A, et al. Expression and regulation of chemokines in murine and human type 1 diabetes. Diabetes (2012) 61(2):436-46. doi:10.2337/db11-0853

52. Calderon B, Suri A, Unanue ER. In CD4+ T-cell-induced diabetes, macrophages are the final effector cells that mediate islet beta-cell killing: studies from an acute model. Am J Pathol (2006) 169(6):2137-47. doi:10.2353/ ajpath.2006.060539

53. Padgett LE, Burg AR, Lei W, Tse HM. Loss of NADPH oxidase-derived superoxide skews macrophage phenotypes to delay type 1 diabetes. Diabetes (2015) 64(3):937-46. doi:10.2337/db14-0929

54. Nikolic T, Geutskens SB, van Rooijen N, Drexhage HA, Leenen PJ. Dendritic cells and macrophages are essential for the retention of lymphocytes in (peri)-insulitis of the nonobese diabetic mouse: a phagocyte depletion study. Lab Invest (2005) 85(4):487-501. doi:10.1038/labinvest. 3700238

55. Ferris ST, Carrero JA, Mohan JF, Calderon B, Murphy KM, Unanue ER. A minor subset of Batf3-dependent antigen-presenting cells in islets of Langerhans is essential for the development of autoimmune diabetes. Immunity (2014) 41(4):657-69. doi:10.1016/j.immuni.2014.09.012

56. Serreze DV, Fleming SA, Chapman HD, Richard SD, Leiter EH, Tisch RM. B lymphocytes are critical antigen-presenting cells for the initiation of $\mathrm{T}$ cell-mediated autoimmune diabetes in nonobese diabetic mice. J Immunol (1998) 161(8):3912-8.

57. Ziegler AG, Vardi P, Ricker AT, Hattori M, Soeldner JS, Eisenbarth GS. Radioassay determination of insulin autoantibodies in NOD mice. Correlation with increased risk of progression to overt diabetes. Diabetes (1989) 38(3):358-63. doi:10.2337/diab.38.3.358

58. Yu L, Robles DT, Abiru N, Kaur P, Rewers M, Kelemen K, et al. Early expression of antiinsulin autoantibodies of humans and the NOD mouse: evidence for early determination of subsequent diabetes. Proc Natl Acad Sci U S A (2000) 97(4):1701-6. doi:10.1073/pnas.040556697

59. Melanitou E, Devendra D, Liu E, Miao D, Eisenbarth GS. Early and quantal (by litter) expression of insulin autoantibodies in the nonobese diabetic mice predict early diabetes onset. JImmunol (2004) 173(11):6603-10. doi:10.4049/jimmunol.173.11.6603

60. Srikanta S, Ganda OP, Rabizadeh A, Soeldner JS, Eisenbarth GS. First-degree relatives of patients with type I diabetes mellitus. Islet-cell antibodies and abnormal insulin secretion. N Engl J Med (1985) 313(8):461-4. doi:10.1056/ NEJM198508223130801

61. Pöllänen PM, Lempainen J, Laine AP, Toppari J, Veijola R, Vähäsalo P, et al. Characterisation of rapid progressors to type 1 diabetes among children with HLA-conferred disease susceptibility. Diabetologia (2017) 60(7):1284-93. doi:10.1007/s00125-017-4258-7

62. Roep BO, Peakman M. Antigen targets of type 1 diabetes autoimmunity. Cold Spring Harb Perspect Med (2012) 2(4):a007781. doi:10.1101/cshperspect. a007781

63. Wenzlau JM, Juhl K, Yu L, Moua O, Sarkar SA, Gottlieb P, et al. The cation efflux transporter ZnT8 (Slc30A8) is a major autoantigen in human type 1 diabetes. Proc Natl Acad Sci U S A (2007) 104(43):17040-5. doi:10.1073/ pnas.0705894104

64. Haskins K, Portas M, Bradley B, Wegmann D, Lafferty K. T-lymphocyte clone specific for pancreatic islet antigen. Diabetes (1988) 37(10):1444-8. doi:10.2337/diab.37.10.1444

65. Haskins K, Portas M, Bergman B, Lafferty K, Bradley B. Pancreatic isletspecific T-cell clones from nonobese diabetic mice. Proc Natl Acad Sci U S A (1989) 86(20):8000-4. doi:10.1073/pnas.86.20.8000

66. Wegmann DR, Shehadeh N, Lafferty KJ, Norbury-Glaser M, Gill RG, Daniel D. Establishment of islet-specific T-cell lines and clones from islet isografts placed in spontaneously diabetic NOD mice. J Autoimmun (1993) 6(5):517-27. doi:10.1006/jaut.1993.1043

67. Haskins K. Pathogenic T-cell clones in autoimmune diabetes: more lessons from the NOD mouse. Adv Immunol (2005) 87:123-62. doi:10.1016/S00652776(05)87004-X

68. Tse HM, Milton MJ, Schreiner S, Profozich JL, Trucco M, Piganelli JD. Disruption of innate-mediated proinflammatory cytokine and reactive oxygen species third signal leads to antigen-specific hyporesponsiveness. J Immunol (2007) 178(2):908-17. doi:10.4049/jimmunol.178.2.908

69. Katz JD, Wang B, Haskins K, Benoist C, Mathis D. Following a diabetogenic $\mathrm{T}$ cell from genesis through pathogenesis. Cell (1993) 74(6):1089-100. doi:10.1016/0092-8674(93)90730-E

70. Han B, Serra P, Amrani A, Yamanouchi J, Marée AF, Edelstein-Keshet L, et al. Prevention of diabetes by manipulation of anti-IGRP autoimmunity: high efficiency of a low-affinity peptide. Nat Med (2005) 11(6):645-52. doi: $10.1038 / \mathrm{nm} 1250$

71. Stadinski BD, Delong T, Reisdorph N, Reisdorph R, Powell RL, Armstrong M, et al. Chromogranin A is an autoantigen in type 1 diabetes. Nat Immunol (2010) 11(3):225-31. doi:10.1038/ni.1844

72. Delong T, Baker RL, Reisdorph N, Reisdorph R, Powell RL, Armstrong M, et al. Islet amyloid polypeptide is a target antigen for diabetogenic CD4+ T cells. Diabetes (2011) 60(9):2325-30. doi:10.2337/db11-0288

73. Baker RL, Delong T, Barbour G, Bradley B, Nakayama M, Haskins K. Cutting edge: $\mathrm{CD} 4 \mathrm{~T}$ cells reactive to an islet amyloid polypeptide peptide accumulate in the pancreas and contribute to disease pathogenesis in nonobese diabetic mice. J Immunol (2013) 191(8):3990-4. doi:10.4049/jimmunol.1301480

74. Wenzlau JM, Walter M, Gardner TJ, Frisch LM, Yu L, Eisenbarth GS, et al. Kinetics of the post-onset decline in zinc transporter 8 autoantibodies in type 1 diabetic human subjects. J Clin Endocrinol Metab (2010) 95(10):4712-9. doi:10.1210/jc.2010-0169

75. Dang M, Rockell J, Wagner R, Wenzlau JM, Yu L, Hutton JC, et al. Human type 1 diabetes is associated with T cell autoimmunity to zinc transporter 8 . J Immunol (2011) 186(10):6056-63. doi:10.4049/jimmunol.1003815

76. Prasad S, Kohm AP, McMahon JS, Luo X, Miller SD. Pathogenesis of NOD diabetes is initiated by reactivity to the insulin B chain 9-23 epitope and involves functional epitope spreading. J Autoimmun (2012) 39(4):347-53. doi:10.1016/j.jaut.2012.04.005

77. Fife BT, Guleria I, Gubbels Bupp M, Eagar TN, Tang Q, Bour-Jordan H, et al. Insulin-induced remission in new-onset NOD mice is maintained by the PD-1-PD-L1 pathway. J Exp Med (2006) 203(12):2737-47. doi:10.1084/ jem.20061577

78. Krishnamurthy B, Dudek NL, McKenzie MD, Purcell AW, Brooks AG, Gellert S, et al. Responses against islet antigens in NOD mice are prevented by tolerance to proinsulin but not IGRP. JClin Invest (2006) 116(12): 3258-65. doi:10.1172/JCI29602

79. DiLorenzo TP. Multiple antigens versus single major antigen in type 1 diabetes: arguing for multiple antigens. Diabetes Metab Res Rev (2011) 27(8):778-83. doi:10.1002/dmrr.1251

80. Jin N, Wang Y, Crawford F, White J, Marrack P, Dai S, et al. N-terminal additions to the WE14 peptide of chromogranin A create strong autoantigen agonists in type 1 diabetes. Proc Natl Acad Sci U S A (2015) 112(43):13318-23. doi:10.1073/pnas.1517862112

81. Delong T, Wiles TA, Baker RL, Bradley B, Barbour G, Reisdorph R, et al. Pathogenic CD4 T cells in type 1 diabetes recognize epitopes formed by peptide fusion. Science (2016) 351(6274):711-4. doi:10.1126/science.aad2791

82. Kracht MJ, van Lummel M, Nikolic T, Joosten AM, Laban S, van der Slik AR, et al. Autoimmunity against a defective ribosomal insulin gene product in type 1 diabetes. Nat Med (2017) 23(4):501-7. doi:10.1038/nm.4289

83. Zhang L, Nakayama M, Eisenbarth GS. Insulin as an autoantigen in NOD/ human diabetes. Curr Opin Immunol (2008) 20(1):111-8. doi:10.1016/ j.coi.2007.11.005

84. Kaufman DL, Clare-Salzler M, Tian J, Forsthuber T, Ting GS, Robinson P, et al. Spontaneous loss of T-cell tolerance to glutamic acid decarboxylase in murine insulin-dependent diabetes. Nature (1993) 366(6450):69-72. doi:10.1038/366069a0

85. Atkinson MA, Kaufman DL, Newman D, Tobin AJ, Maclaren NK. Islet cell cytoplasmic autoantibody reactivity to glutamate decarboxylase in insulin-dependent diabetes. J Clin Invest (1993) 91(1):350-6. doi:10.1172/JCI116192

86. Schloot NC, Daniel D, Norbury-Glaser M, Wegmann DR. Peripheral T cell clones from NOD mice specific for GAD65 peptides: lack of islet responsiveness or diabetogenicity. J Autoimmun (1996) 9(3):357-63. doi:10.1006/ jaut.1996.0048

87. Videbaek N, Harach S, Phillips J, Hutchings P, Ozegbe P, Michelsen BK, et al. An islet-homing NOD CD8+ cytotoxic T cell clone recognizes GAD65 and causes insulitis. J Autoimmun (2003) 20(2):97-109. doi:10.1016/S08968411(03)00003-9 
88. Ott PA, Dittrich MT, Herzog BA, Guerkov R, Gottlieb PA, Putnam AL, et al. T cells recognize multiple GAD65 and proinsulin epitopes in human type 1 diabetes, suggesting determinant spreading. J Clin Immunol (2004) 24(4):327-39. doi:10.1023/B:JOCI.0000029120.77824.41

89. Wenzlau JM, Frisch LM, Hutton JC, Davidson HW. Mapping of conformational autoantibody epitopes in ZNT8. Diabetes Metab Res Rev (2011) 27(8):883-6. doi:10.1002/dmrr.1266

90. Énée É, Kratzer R, Arnoux JB, Barilleau E, Hamel Y, Marchi C, et al. ZnT8 is a major CD8+ T cell-recognized autoantigen in pediatric type 1 diabetes. Diabetes (2012) 61(7):1779-84. doi:10.2337/db12-0071

91. Xu X, Gu Y, Bian L, Shi Y, Cai Y, Chen Y, et al. Characterization of immune response to novel HLA-A2-restricted epitopes from zinc transporter 8 in type 1 diabetes. Vaccine (2016) 34(6):854-62. doi:10.1016/j.vaccine. 2015.10.108

92. Nayak DK, Calderon B, Vomund AN, Unanue ER. ZnT8-reactive T cells are weakly pathogenic in NOD mice but can participate in diabetes under inflammatory conditions. Diabetes (2014) 63(10):3438-48. doi:10.2337/ db13-1882

93. Kubosaki A, Miura J, Notkins AL. IA-2 is not required for the development of diabetes in NOD mice. Diabetologia (2004) 47(1):149-50. doi:10.1007/ s00125-003-1252-z

94. Ouyang Q, Standifer NE, Qin H, Gottlieb P, Verchere CB, Nepom GT, et al. Recognition of HLA class I-restricted beta-cell epitopes in type 1 diabetes. Diabetes (2006) 55(11):3068-74. doi:10.2337/db06-0065

95. Zhao Z, Miao D, Michels A, Steck A, Dong F, Rewers M, et al. A multiplex assay combining insulin, GAD, IA-2 and transglutaminase autoantibodies to facilitate screening for pre-type 1 diabetes and celiac disease. J Immunol Methods (2016) 430:28-32. doi:10.1016/j.jim.2016.01.011

96. Kawasaki E, Hutton JC, Eisenbarth GS. Molecular cloning and characterization of the human transmembrane protein tyrosine phosphatase homologue, phogrin, an autoantigen of type 1 diabetes. Biochem Biophys Res Commun (1996) 227(2):440-7. doi:10.1006/bbrc.1996.1526

97. Kawasaki E, Eisenbarth GS, Wasmeier C, Hutton JC. Autoantibodies to protein tyrosine phosphatase-like proteins in type I diabetes. Overlapping specificities to phogrin and ICA512/IA-2. Diabetes (1996) 45(10):1344-9. doi:10.2337/diab.45.10.1344

98. Kelemen K, Crawford ML, Gill RG, Hutton JC, Wegmann D. Cellular immune response to phogrin in the NOD mouse: cloned T-cells cause destruction of islet transplants. Diabetes (1999) 48(8):1529-34. doi:10.2337/ diabetes.48.8.1529

99. Kelemen K, Gottlieb PA, Putnam AL, Davidson HW, Wegmann DR, Hutton JC. HLA-DQ8-associated T cell responses to the diabetes autoantigen phogrin (IA-2 beta) in human prediabetes. J Immunol (2004) 172(6): 3955-62. doi:10.4049/jimmunol.172.6.3955

100. Karges W, Hammond-McKibben D, Gaedigk R, Shibuya N, Cheung R, Dosch HM. Loss of self-tolerance to ICA69 in nonobese diabetic mice. Diabetes (1997) 46(10):1548-56. doi:10.2337/diabetes.46.10.1548

101. Winer S, Astsaturov I, Gaedigk R, Hammond-McKibben D, Pilon M, Song A, et al. ICA69(null) nonobese diabetic mice develop diabetes, but resist disease acceleration by cyclophosphamide. J Immunol (2002) 168(1):475-82. doi:10.4049/jimmunol.168.1.475

102. Winer S, Tsui H, Lau A, Song A, Li X, Cheung RK, et al. Autoimmune islet destruction in spontaneous type 1 diabetes is not beta-cell exclusive. Nat Med (2003) 9(2):198-205. doi:10.1038/nm818

103. Chen W, Bergerot I, Elliott JF, Harrison LC, Abiru N, Eisenbarth GS, et al. Evidence that a peptide spanning the B-C junction of proinsulin is an early autoantigen epitope in the pathogenesis of type 1 diabetes. J Immunol (2001) 167(9):4926-35. doi:10.4049/jimmunol.167.9.4926

104. Gottlieb PA, Delong T, Baker RL, Fitzgerald-Miller L, Wagner R, Cook G, et al. Chromogranin A is a $\mathrm{T}$ cell antigen in human type 1 diabetes. J Autoimmun (2014) 50:38-41. doi:10.1016/j.jaut.2013.10.003

105. Nikoopour E, Krougly O, Lee-Chan E, Haeryfar SM, Singh B. Detection of vasostatin-1-specific CD8(+) T cells in non-obese diabetic mice that contribute to diabetes pathogenesis. Clin Exp Immunol (2016) 185(3):292-300. doi:10.1111/cei.12811

106. Viret C, Mahiddine K, Baker RL, Haskins K, Guerder S. The T cell repertoire-diversifying enzyme TSSP contributes to thymic selection of diabetogenic CD4 T cell specificities reactive to ChgA and IAPP autoantigens. J Immunol (2015) 195(5):1964-73. doi:10.4049/jimmunol.1401683
107. Wiles TA, Delong T, Baker RL, Bradley B, Barbour G, Powell RL, et al. An insulin-IAPP hybrid peptide is an endogenous antigen for CD4 T cells in the non-obese diabetic mouse. J Autoimmun (2017) 78:11-8. doi:10.1016/ j.jaut.2016.10.007

108. Yang J, Danke NA, Berger D, Reichstetter S, Reijonen H, Greenbaum C, et al. Islet-specific glucose-6-phosphatase catalytic subunit-related proteinreactive CD4+ T cells in human subjects. J Immunol (2006) 176(5):2781-9. doi:10.4049/jimmunol.176.5.2781

109. Ko HJ, Chee J, Sutherland RM, Thomas HE, Zhan Y, Krishnamurthy B, et al. Functional cytotoxic T lymphocytes against IGRP206-214 predict diabetes in the non-obese diabetic mouse. Immunol Cell Biol (2014) 92(7):640-4. doi:10.1038/icb.2014.29

110. Chentoufi AA, Polychronakos C. Insulin expression levels in the thymus modulate insulin-specific autoreactive T-cell tolerance: the mechanism by which the IDDM2 locus may predispose to diabetes. Diabetes (2002) 51(5): 1383-90. doi:10.2337/diabetes.51.5.1383

111. Marrack P, Kappler JW. Do MHCII-presented neoantigens drive type 1 diabetes and other autoimmune diseases? Cold Spring Harb Perspect Med (2012) 2(9):a007765. doi:10.1101/cshperspect.a007765

112. Lamhamedi-Cherradi SE, Luan JJ, Eloy L, Fluteau G, Bach JF, Garchon HJ. Resistance of T-cells to apoptosis in autoimmune diabetic (NOD) mice is increased early in life and is associated with dysregulated expression of Bcl-x. Diabetologia (1998) 41(2):178-84. doi:10.1007/s001250050887

113. Pugliese A, Zeller M, Fernandez A Jr, Zalcberg LJ, Bartlett RJ, Ricordi C, et al. The insulin gene is transcribed in the human thymus and transcription levels correlated with allelic variation at the INS VNTR-IDDM2 susceptibility locus for type 1 diabetes. Nat Genet (1997) 15(3):293-7. doi:10.1038/ ng0397-293

114. Regnault B, Osorio Y Fortea J, Miao D, Eisenbarth G, Melanitou E. Early over expression of messenger RNA for multiple genes, including insulin, in the pancreatic lymph nodes of NOD mice is associated with islet autoimmunity. BMC Med Genomics (2009) 2:63. doi:10.1186/1755-8794-2-63

115. Thomas JW, Hulbert C. Somatically mutated B cell pool provides precursors for insulin antibodies. J Immunol (1996) 157(2):763-71.

116. Pauken KE, Linehan JL, Spanier JA, Sahli NL, Kalekar LA, Binstadt BA, et al. Cutting edge: type 1 diabetes occurs despite robust anergy among endogenous insulin-specific CD4 T cells in NOD mice. JImmunol (2013) 191(10):4913-7. doi:10.4049/jimmunol.1301927

117. Martinez RJ, Zhang N, Thomas SR, Nandiwada SL, Jenkins MK, Binstadt BA, et al. Arthritogenic self-reactive CD4+ T cells acquire an FR4hiCD73hi anergic state in the presence of Foxp3+ regulatory T cells. J Immunol (2012) 188(1):170-81. doi:10.4049/jimmunol.1101311

118. Kitagawa Y, Sakaguchi S. Molecular control of regulatory T cell development and function. Curr Opin Immunol (2017) 49:64-70. doi:10.1016/j. coi.2017.10.002

119. Johnson MC, Garland AL, Nicolson SC, Li C, Samulski RJ, Wang B, et al. Betacell-specific IL-2 therapy increases islet Foxp3+Treg and suppresses type 1 diabetes in NOD mice. Diabetes (2013) 62(11):3775-84. doi:10.2337/db13-0669

120. Davies JD, Leong LY, Mellor A, Cobbold SP, Waldmann H. T cell suppression in transplantation tolerance through linked recognition. J Immunol (1996) 156(10):3602-7.

121. Waldmann H, Cobbold S. How do monoclonal antibodies induce tolerance? A role for infectious tolerance? Annu Rev Immunol (1998) 16:619-44. doi:10.1146/annurev.immunol.16.1.619

122. Anderton SM, Wraith DC. Hierarchy in the ability of $\mathrm{T}$ cell epitopes to induce peripheral tolerance to antigens from myelin. Eur J Immunol (1998) 28(4):1251-61. doi:10.1002/(SICI)1521-4141(199804)28:04<1251:: AID-IMMU1251>3.0.CO;2-O

123. Ito T, Yamada A, Batal I, Yeung MY, McGrath MM, Sayegh MH, et al. The limits of linked suppression for regulatory T cells. Front Immunol (2016) 7:82. doi:10.3389/fimmu.2016.00082

124. Itoh A, Ridgway WM. Targeting innate immunity to downmodulate adaptive immunity and reverse type 1 diabetes. Immunotargets Ther (2017) 6:31-8. doi:10.2147/ITT.S117264

125. Reed JC, Herold KC. Thinking bedside at the bench: the NOD mouse model of T1DM. Nat Rev Endocrinol (2015) 11(5):308-14. doi:10.1038/ nrendo.2014.236

126. Prasad S, Xu D, Miller SD. Tolerance strategies employing antigen-coupled apoptotic cells and carboxylated PLG nanoparticles for the treatment of 
type 1 diabetes. Rev Diabet Stud (2012) 9(4):319-27. doi:10.1900/RDS. 2012.9.319

127. Mahne AE, Klementowicz JE, Chou A, Nguyen V, Tang Q. Therapeutic regulatory $\mathrm{T}$ cells subvert effector $\mathrm{T}$ cell function in inflamed islets to halt autoimmune diabetes. JImmunol (2015) 194(7):3147-55. doi:10.4049/ jimmunol.1402739

128. Tang Q, Adams JY, Penaranda C, Melli K, Piaggio E, Sgouroudis E, et al. Central role of defective interleukin-2 production in the triggering of islet autoimmune destruction. Immunity (2008) 28(5):687-97. doi:10.1016/ j.immuni.2008.03.016

129. Grinberg-Bleyer Y, Baeyens A, You S, Elhage R, Fourcade G, Gregoire S, et al. IL-2 reverses established type 1 diabetes in NOD mice by a local effect on pancreatic regulatory T cells. J Exp Med (2010) 207(9):1871-8. doi:10.1084/ jem.20100209

130. Marek-Trzonkowska N, Mysliwiec M, Dobyszuk A, Grabowska M, Techmanska I, Juscinska J, et al. Administration of CD4+CD25highCD127regulatory $\mathrm{T}$ cells preserves beta-cell function in type 1 diabetes in children. Diabetes Care (2012) 35(9):1817-20. doi:10.2337/dc12-0038

131. Marek-Trzonkowska N, Myśliwiec M, Dobyszuk A, Grabowska M, Derkowska I, Juścińska J, et al. Therapy of type 1 diabetes with CD4(+) CD25(high)CD127-regulatory $\mathrm{T}$ cells prolongs survival of pancreatic islets - results of one year follow-up. Clin Immunol (2014) 153(1):23-30. doi:10.1016/j.clim.2014.03.016

132. Putnam AL, Brusko TM, Lee MR, Liu W, Szot GL, Ghosh T, et al. Expansion of human regulatory T-cells from patients with type 1 diabetes. Diabetes (2009) 58(3):652-62. doi:10.2337/db08-1168

133. Bluestone JA, Buckner JH, Fitch M, Gitelman SE, Gupta S, Hellerstein MK, et al. Type 1 diabetes immunotherapy using polyclonal regulatory $\mathrm{T}$ cells. Sci Transl Med (2015) 7(315):315ra189. doi:10.1126/scitranslmed.aad4134

134. Seay HR, Putnam AL, Cserny J, Posgai AL, Rosenau EH, Wingard JR, et al. Expansion of human Tregs from cryopreserved umbilical cord blood for GMP-compliant autologous adoptive cell transfer therapy. Mol Ther Methods Clin Dev (2017) 4:178-91. doi:10.1016/j.omtm.2016.12.003

135. Megaw R, Dhillon B. Stem cell therapies in the management of diabetic retinopathy. Curr Diab Rep (2014) 14(7):498. doi:10.1007/s11892-014-0498-9

136. Mora-Fernández C, Domínguez-Pimentel V, de Fuentes MM, Górriz JL, Martínez-Castelao A, Navarro-González JF. Diabetic kidney disease: from physiology to therapeutics. J Physiol (2014) 592(18):3997-4012. doi:10.1113/ jphysiol.2014.272328

137. Aslam A, Singh J, Rajbhandari S. Pathogenesis of painful diabetic neuropathy. Pain Res Treat (2014) 2014:412041. doi:10.1155/2014/412041

138. Letonja M, Petrovic D. Is diabetic cardiomyopathy a specific entity? World J Cardiol (2014) 6(1):8-13. doi:10.4330/wjc.v6.i1.8

139. Boudina S, Abel ED. Diabetic cardiomyopathy, causes and effects. Rev Endocr Metab Disord (2010) 11(1):31-9. doi:10.1007/s11154-010-9131-7

140. Mukherjee G, Chaparro RJ, Schloss J, Smith C, Bando CD, DiLorenzo TP. Glucagon-reactive islet-infiltrating CD8 T cells in NOD mice. Immunology (2015) 144(4):631-40. doi:10.1111/imm.12415

141. Mundinger TO, Mei Q, Foulis AK, Fligner CL, Hull RL, Taborsky GJ Jr. Human type 1 diabetes is characterized by an early, marked, sustained, and islet-selective loss of sympathetic nerves. Diabetes (2016) 65(8):2322-30. doi:10.2337/db16-0284

142. McLaughlin KA, Richardson CC, Ravishankar A, Brigatti C, Liberati D, Lampasona $\mathrm{V}$, et al. Identification of tetraspanin-7 as a target of autoantibodies in type 1 diabetes. Diabetes (2016) 65(6):1690-8. doi:10.2337/ db15-1058

143. Pagliuca FW, Millman JR, Gürtler M, Segel M, Van Dervort A, Ryu JH, et al. Generation of functional human pancreatic beta cells in vitro. Cell (2014) 159(2):428-39. doi:10.1016/j.cell.2014.09.040

144. Rezania A, Bruin JE, Arora P, Rubin A, Batushansky I, Asadi A, et al. Reversal of diabetes with insulin-producing cells derived in vitro from human pluripotent stem cells. Nat Biotechnol (2014) 32(11):1121-33. doi:10.1038/ nbt.3033

145. Bose B, Sudheer PS. In vitro differentiation of pluripotent stem cells into functional beta islets under $2 \mathrm{D}$ and $3 \mathrm{D}$ culture conditions and in vivo preclinical validation of 3D islets. Methods Mol Biol (2016) 1341:257-84. doi:10.1007/7651_2015_230

146. Rajaei B, Shamsara M, Amirabad LM, Massumi M, Sanati MH. Pancreatic endoderm-derived from diabetic patient-specific induced pluripotent stem cell generates glucose-responsive insulin-secreting cells. J Cell Physiol (2017) 232(10):2616-25. doi:10.1002/jcp.25459

147. Ryan EA, Lakey JR, Rajotte RV, Korbutt GS, Kin T, Imes S, et al. Clinical outcomes and insulin secretion after islet transplantation with the Edmonton protocol. Diabetes (2001) 50(4):710-9. doi:10.2337/diabetes.50.4.710

148. Ryan EA, Paty BW, Senior PA, Bigam D, Alfadhli E, Kneteman NM, et al. Five-year follow-up after clinical islet transplantation. Diabetes (2005) 54(7):2060-9. doi:10.2337/diabetes.54.7.2060

149. Ricordi C, Goldstein JS, Balamurugan AN, Szot GL, Kin T, Liu C, et al. National Institutes of Health-Sponsored Clinical Islet Transplantation Consortium phase 3 trial: manufacture of a complex cellular product at eight processing facilities. Diabetes (2016) 65(11):3418-28. doi:10.2337/db16-0234

150. Shapiro AM, Pokrywczynska M, Ricordi C. Clinical pancreatic islet transplantation. Nat Rev Endocrinol (2017) 13(5):268-77. doi:10.1038/nrendo. 2016.178

151. Assalino M, Genevay M, Morel P, Demuylder-Mischler S, Toso C, Berney T. Recurrence of type 1 diabetes after simultaneous pancreas-kidney transplantation in the absence of GAD and IA-2 autoantibodies. Am J Transplant (2012) 12(2):492-5. doi:10.1111/j.1600-6143.2011.03844.x

152. Burke GW III, Vendrame F, Pileggi A, Ciancio G, Reijonen H, Pugliese A. Recurrence of autoimmunity following pancreas transplantation. Curr Diab Rep (2011) 11(5):413-9. doi:10.1007/s11892-011-0206-y

153. Chakravarthy H, Gu X, Enge M, Dai X, Wang Y, Damond N, et al. Converting adult pancreatic islet alpha cells into beta cells by targeting both Dnmt1 and Arx. Cell Metab (2017) 25(3):622-34. doi:10.1016/j.cmet.2017.01.009

154. Burke GW III, Vendrame F, Virdi SK, Ciancio G, Chen L, Ruiz P, et al. Lessons from pancreas transplantation in type 1 diabetes: recurrence of islet autoimmunity. Curr Diab Rep (2015) 15(12):121. doi:10.1007/s11892-015-0691-5

155. Chang CA, Lawrence MC, Naziruddin B. Current issues in allogeneic islet transplantation. Curr Opin Organ Transplant (2017) 22(5):437-43. doi:10.1097/MOT.0000000000000448

156. Reffet S, Thivolet C. Immunology of pancreatic islet transplantation. Diabetes Metab (2006) 32(5 Pt 2):523-6. doi:10.1016/S1262-3636(06)72805-1

157. Lin CM, Gill RG. Direct and indirect allograft recognition: pathways dictating graft rejection mechanisms. Curr Opin Organ Transplant (2016) 21(1): 40-4. doi:10.1097/MOT.0000000000000263

158. Sherman LA, Chattopadhyay S. The molecular basis of allorecognition. Annu Rev Immunol (1993) 11:385-402. doi:10.1146/annurev.iy.11.040193. 002125

159. Brennan TV, Jaigirdar A, Hoang V, Hayden T, Liu FC, Zaid H, et al. Preferential priming of alloreactive $\mathrm{T}$ cells with indirect reactivity. Am J Transplant (2009) 9(4):709-18. doi:10.1111/j.1600-6143.2009.02578.x

160. Frank R, Molina MR, Goldberg LR, Wald JW, Kamoun M, Lal P. Circulating donor-specific anti-human leukocyte antigen antibodies and complement C4d deposition are associated with the development of cardiac allograft vasculopathy. Am JClin Pathol (2014) 142(6):809-15. doi:10.1309/ AJCPTLBEU5BQ8SHN

161. Zhao Y, Scott NA, Quah HS, Krishnamurthy B, Bond F, Loudovaris T, et al. Mouse pancreatic beta cells express MHC class II and stimulate CD4(+) T cells to proliferate. Eur J Immunol (2015) 45(9):2494-503. doi:10.1002/ eji.201445378

162. Makhlouf L, Kishimoto K, Smith RN, Abdi R, Koulmanda M, Winn HJ, et al. The role of autoimmunity in islet allograft destruction: major histocompatibility complex class II matching is necessary for autoimmune destruction of allogeneic islet transplants after T-cell costimulatory blockade. Diabetes (2002) 51(11):3202-10. doi:10.2337/diabetes.51.11.3202

163. Kupfer TM, Crawford ML, Pham K, Gill RG. MHC-mismatched islet allografts are vulnerable to autoimmune recognition in vivo. J Immunol (2005) 175(4):2309-16. doi:10.4049/jimmunol.175.4.2309

164. Makhlouf L, Yamada A, Ito T, Abdi R, Ansari MJ, Khuong CQ, et al. Allorecognition and effector pathways of islet allograft rejection in normal versus nonobese diabetic mice. J Am Soc Nephrol (2003) 14(8):2168-75. doi:10.1097/01.ASN.0000079041.15707.A9

165. Nicolls MR, Coulombe M, Beilke J, Gelhaus HC, Gill RG. CD4-dependent generation of dominant transplantation tolerance induced by simultaneous perturbation of CD154 and LFA-1 pathways. J Immunol (2002) 169(9): 4831-9. doi:10.4049/jimmunol.169.9.4831

166. Gerling IC, Friedman H, Greiner DL, Shultz LD, Leiter EH. Multiple lowdose streptozocin-induced diabetes in NOD-scid/scid mice in the absence 
of functional lymphocytes. Diabetes (1994) 43(3):433-40. doi:10.2337/ diab.43.3.433

167. Lukic ML, Stosic-Grujicic S, Shahin A. Effector mechanisms in low-dose streptozotocin-induced diabetes. Dev Immunol (1998) 6(1-2):119-28. doi:10.1155/1998/92198

168. Gala-Lopez B, Pepper AR, Shapiro AM. Biologic agents in islet transplantation. Curr Diab Rep (2013) 13(5):713-22. doi:10.1007/s11892-013-0414-8

169. Kimelman M, Brandacher G. Trends in immunosuppression after pancreas transplantation: what is in the pipeline? Curr Opin Organ Transplant (2013) 18(1):76-82. doi:10.1097/MOT.0b013e32835c6eda

170. Wang S, Zhang X, Zhang L, Bryant J, Kheradmand T, Hering BJ, et al. Preemptive tolerogenic delivery of donor antigens for permanent allogeneic islet graft protection. Cell Transplant (2015) 24(6):1155-65. doi:10.3727/ 096368914 X681027

171. Nanji SA, Hancock WW, Luo B, Schur CD, Pawlick RL, Zhu LF, et al. Costimulation blockade of both inducible costimulator and CD40 ligand induces dominant tolerance to islet allografts and prevents spontaneous autoimmune diabetes in the NOD mouse. Diabetes (2006) 55(1):27-33. doi:10.2337/diabetes.55.01.06.db04-1154

172. Ferrer IR, Wagener ME, Song M, Kirk AD, Larsen CP, Ford ML. Antigenspecific induced Foxp3+ regulatory T cells are generated following CD40/ CD154 blockade. Proc Natl Acad Sci U S A (2011) 108(51):20701-6. doi:10.1073/pnas.1105500108

173. Beilke JN, Kuhl NR, Van Kaer L, Gill RG. NK cells promote islet allograft tolerance via a perforin-dependent mechanism. Nat Med (2005) 11(10): 1059-65. doi:10.1038/nm1296

174. Nicolls MR, Coulombe M, Gill RG. The basis of immunogenicity of endocrine allografts. Crit Rev Immunol (2001) 21(1-3):87-101. doi:10.1615/ CritRevImmunol.v21.i1-3.60

175. Coulombe M, Yang H, Wolf LA, Gill RG. Tolerance to antigen-presenting cell-depleted islet allografts is CD4 T cell dependent. J Immunol (1999) 162(5):2503-10.

176. Yolcu ES, Zhao H, Bandura-Morgan L, Lacelle C, Woodward KB, Askenasy N, et al. Pancreatic islets engineered with SA-FasL protein establish robust localized tolerance by inducing regulatory $\mathrm{T}$ cells in mice. J Immunol (2011) 187(11):5901-9. doi:10.4049/jimmunol.1003266

177. El Khatib MM, Sakuma T, Tonne JM, Mohamed MS, Holditch SJ, Lu B, et al. Beta-cell-targeted blockage of PD1 and CTLA4 pathways prevents development of autoimmune diabetes and acute allogeneic islets rejection. Gene Ther (2015) 22(5):430-8. doi:10.1038/gt.2015.18

178. Moore DJ, Noorchashm H, Lin TH, Greeley SA, Naji A. NOD B-cells are insufficient to incite T-cell-mediated anti-islet autoimmunity. Diabetes (2005) 54(7):2019-25. doi:10.2337/diabetes.54.7.2019

179. Zheng XX, Sánchez-Fueyo A, Sho M, Domenig C, Sayegh MH, Strom TB. Favorably tipping the balance between cytopathic and regulatory $\mathrm{T}$ cells to create transplantation tolerance. Immunity (2003) 19(4):503-14. doi:10.1016/ S1074-7613(03)00259-0

180. Markees TG, Serreze DV, Phillips NE, Sorli CH, Gordon EJ, Shultz LD, et al. NOD mice have a generalized defect in their response to transplantation tolerance induction. Diabetes (1999) 48(5):967-74. doi:10.2337/diabetes.48.5.967

181. Li L, Wang B, Frelinger JA, Tisch R. T-cell promiscuity in autoimmune diabetes. Diabetes (2008) 57(8):2099-106. doi:10.2337/db08-0383

182. Molano RD, Berney T, Li H, Cattan P, Pileggi A, Vizzardelli C, et al. Prolonged islet graft survival in NOD mice by blockade of the CD40-CD154 pathway of T-cell costimulation. Diabetes (2001) 50(2):270-6. doi:10.2337/ diabetes.50.2.270

183. Wang Y, Pontesilli O, Gill RG, La Rosa FG, Lafferty KJ. The role of CD4+ and CD8+ T cells in the destruction of islet grafts by spontaneously diabetic mice. Proc Natl Acad Sci U S A (1991) 88(2):527-31. doi:10.1073/ pnas.88.2.527

184. Drage M, Zaccone P, Phillips JM, Nicoletti F, Dawson J, Andrew Bradley $\mathrm{J}$, et al. Nondepleting anti-CD4 and soluble interleukin-1 receptor prevent autoimmune destruction of syngeneic islet grafts in diabetic NOD mice. Transplantation(2002)74(5):611-9. doi:10.1097/00007890-200209150-00005

185. Berney T, Pileggi A, Molano RD, Poggioli R, Zahr E, Ricordi C, et al. The effect of simultaneous CD154 and LFA-1 blockade on the survival of allogeneic islet grafts in nonobese diabetic mice. Transplantation (2003) 76(12):1669-74. doi:10.1097/01.TP.0000092525.17025.D0
186. Naji A, Silvers WK, Bellgrau D, Barker CF. Spontaneous diabetes in rats: destruction of islets is prevented by immunological tolerance. Science (1981) 213(4514):1390-2. doi:10.1126/science.6791286

187. Naji A, Bellgrau D, Anderson A, Silvers WK, Barker CF. Transplantation of islets and bone marrow cells to animals with immune insulitis. Diabetes (1982) 31(Suppl 4):84-91. doi:10.2337/diab.31.4.S84

188. Naji A, Silvers WK, Kimura H, Bellgrau D, Markmann JF, Barker CF. Analytical and functional studies on the $\mathrm{T}$ cells of untreated and immunologically tolerant diabetes-prone BB rats. J Immunol (1983) 130(5):2168-72.

189. Prowse SJ, Bellgrau D, Lafferty KJ. Islet allografts are destroyed by disease occurrence in the spontaneously diabetic BB rat. Diabetes (1986) 35(1):110-4. doi:10.2337/diab.35.1.110

190. Langsford D, Dwyer K. Dysglycemia after renal transplantation: definition, pathogenesis, outcomes and implications for management. World J Diabetes (2015) 6(10):1132-51. doi:10.4239/wjd.v6.i10.1132

191. Oling V, Marttila J, Ilonen J, Kwok WW, Nepom G, Knip M, et al. GAD65and proinsulin-specific CD4+ T-cells detected by MHC class II tetramers in peripheral blood of type 1 diabetes patients and at-risk subjects. J Autoimmun (2005) 25(3):235-43. doi:10.1016/j.jaut.2005.09.018

192. Yang J, Danke N, Roti M, Huston L, Greenbaum C, Pihoker C, et al. CD4+ $\mathrm{T}$ cells from type 1 diabetic and healthy subjects exhibit different thresholds of activation to a naturally processed proinsulin epitope. JAutoimmun (2008) 31(1):30-41. doi:10.1016/j.jaut.2008.02.001

193. Yang J, Chow IT, Sosinowski T, Torres-Chinn N, Greenbaum CJ, James EA, et al. Autoreactive T cells specific for insulin B:11-23 recognize a low-affinity peptide register in human subjects with autoimmune diabetes. Proc Natl Acad Sci U S A (2014) 111(41):14840-5. doi:10.1073/pnas.1416864111

194. Spanier JA, Sahli NL, Wilson JC, Martinov T, Dileepan T, Burrack AL, et al. Increased effector memory insulin-specific $\mathrm{CD} 4+\mathrm{T}$-cells correlate with insulin autoantibodies in recent-onset type 1 diabetic patients. Diabetes (2017) 66(12):3051-60. doi:10.2337/db17-0666

195. Antkowiak PF, Tersey SA, Carter JD, Vandsburger MH, Nadler JL, Epstein FH, et al. Noninvasive assessment of pancreatic beta-cell function in vivo with manganese-enhanced magnetic resonance imaging. Am J Physiol Endocrinol Metab (2009) 296(3):E573-8. doi:10.1152/ajpendo. 90336.2008

196. Gaglia JL, Guimaraes AR, Harisinghani M, Turvey SE, Jackson R, Benoist $\mathrm{C}$, et al. Noninvasive imaging of pancreatic islet inflammation in type $1 \mathrm{~A}$ diabetes patients. J Clin Invest (2011) 121(1):442-5. doi:10.1172/JCI44339

197. Demeester S, Keymeulen B, Kaufman L, Van Dalem A, Balti EV, Van de Velde $\mathrm{U}$, et al. Preexisting insulin autoantibodies predict efficacy of otelixizumab in preserving residual beta-cell function in recent-onset type 1 diabetes. Diabetes Care (2015) 38(4):644-51. doi:10.2337/dc14-1575

198. Akirav EM, Lebastchi J, Galvan EM, Henegariu O, Akirav M, Ablamunits $\mathrm{V}$, et al. Detection of beta cell death in diabetes using differentially methylated circulating DNA. Proc Natl Acad Sci U S A (2011) 108(47): 19018-23. doi:10.1073/pnas.1111008108

199. Olsen JA, Kenna LA, Spelios MG, Hessner MJ, Akirav EM. Circulating differentially methylated amylin DNA as a biomarker of beta-cell loss in type 1 diabetes. PLoS One (2016) 11(4):e0152662. doi:10.1371/journal.pone.0152662

200. Su CA, Iida S, Abe T, Fairchild RL. Endogenous memory CD8 T cells directly mediate cardiac allograft rejection. Am J Transplant (2014) 14(3): 568-79. doi:10.1111/ajt.12605

201. Gorbacheva V, Fan R, Fairchild RL, Baldwin WM III, Valujskikh A. Memory CD4 T cells induce antibody-mediated rejection of renal allografts. J Am Soc Nephrol (2016) 27(11):3299-307. doi:10.1681/ASN.2015080848

Conflict of Interest Statement: The authors declare that the research was conducted in the absence of any commercial or financial relationships that could be construed as a potential conflict of interest.

Copyright $(\odot 2017$ Burrack, Martinov and Fife. This is an open-access article distributed under the terms of the Creative Commons Attribution License (CC BY). The use, distribution or reproduction in other forums is permitted, provided the original author(s) or licensor are credited and that the original publication in this journal is cited, in accordance with accepted academic practice. No use, distribution or reproduction is permitted which does not comply with these terms. 